\title{
$P-T$ and structural constraints of lawsonite and epidote blueschists from Liberty Creek and Seldovia: Tectonic implications for early stages of subduction along the southern Alaska convergent margin
}

\author{
Alicia López-Carmona , Timothy M. Kusky , M. Santosh , Jacobo Abati \\ a Departamento de Petrología y Geoquímica and Instituto de Geología Económica, Universidad Complutense-Consejo Superior de Investigaciones Científicas, 28040 Madrid, Spain

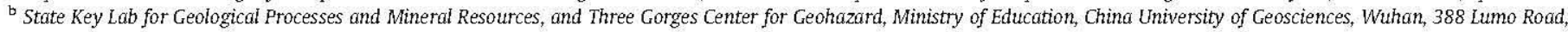 \\ Hongshan District, Wuhan 430074, China \\ ${ }^{c}$ Department of Interdisciplinary Science, Faculty of Science, Kochi University, Akebono-cho 2-5-1, Kochi 780-8520, Japan
}

Keywords:

Alaska

Blueschist

Subduction

Border Ranges Fault

PT pseudosections

\begin{abstract}
A B S T R A C T
The southern Alaska convergent margin contains several small belts of sedimentary and volcanic rocks metamorphosed to blueschist facies, located along the Border Ranges fault on the contact between the Wrangellia and Chugach terranes. These belts are significant in that they are the most inboard, and thus probably contain the oldest record of Triassic-Jurassic northward-directed subduction beneath Wrangellia. The Liberty Creek HP-LT schist belt is the oldest and the innermost section of the Chugach terrane. Within this belt lawsonite blueschists contains an initial high-pressure assemblage formed by lawsonite + phengite + chlorite + sphene + albite \pm apatite \pm carbonates and quartz. Epidote blueschists are composed of sodic, sodic-calcic and calcic amphiboles + epidote + phengite + chlorite + albite + sphene \pm carbonates and quartz. $P-T$ pseudosections computed from four representative samples constrain maximum pressures at $16 \mathrm{kbar}$ and $250-280^{\circ} \mathrm{C}$ for the Lawsonite-bearing blueschists, and $15 \mathrm{kbar}$ and $400-500^{\circ} \mathrm{C}$ for the epidote-bearing blueschists, suggesting a initial subduction stage of $50-55 \mathrm{~km}$ depth. The growth of late albite porphyroblasts in all samples suggests a dramatic decompression from ca. $9 \mathrm{kbar}$ to $5 \mathrm{kbar}$. The Liberty Creek schists can be correlated with the Seldovia blueschist belt on the Kenai Peninsula. Metamorphism in both terranes took place in the Early Jurassic (191-192 Ma), recording an early stage of subduction beneath Wrangellia. In the nearby terranes of the same margin, the age of metamorphism records an early stage of subduction at $230 \mathrm{Ma}$. Based on this difference in age, a maximum of $40 \mathrm{Ma}$ were necessary to subduct the protoliths of the Seldovia and Liberty Creek blueschists to depths of circa 50-55 km, suggesting a minimum vertical component of subduction of $1.2-1.5 \mathrm{~cm} / \mathrm{year}$.
\end{abstract}

\section{Introduction}

Blueschists and related HP/LT (high-pressure/low-temperature) assemblages are considered as markers of fossil subduction zones, and record the tectonic processes associated with convergent plate boundaries (e.g. Maruyama et al., 1996). Recent petrological and geochronological studies of blueschist facies and associated rocks have provided important clues in understanding subduction zone metamorphism (e.g. Isozaki et al., 2010; López-Carmona et al, 2010), thermotectonic evolution (e.g., Z. Zhang et al., 2009) and the styles of exhumation, such as the in the case of the world's youngest blueschist from Leti Island in eastern Indonesia (Kadarusman et al., 2010). In a recent review, Ota and Kaneko (2010) synthesized the petrologic

\footnotetext{
* Corresponding author.

E-mail addresses: alcarmona@geo.ucm.es (A. López-Carmona), tkusky@gmail.com (T.M. Kusky), santosh@cc.kochi-u.ac.jp (M. Santosh), abati@geo.ucm.es (J. Abati).
}

information from blueschist facies rocks worldwide and showed that in most cases, their $P-T$ field is bounded on the low-P side by greenschist and pumpellyite-actinolite facies, on the high- $T$ side by epidoteamphibolite facies, and the high- $P$ and high- $T$ sides by eclogite facies. Among the rocks belonging to these metamorphic facies, blueschists and eclogites manifest lithospheric plate subduction, because these rocks, especially blueschists, require unusually cold upper mantle geotherms which are only found in active subduction zones (e.g., Ernst, 2010; Omori et al., 2009). Thus, the space-time distribution of blueschist eclogite belts have been regarded as markers of paleosubduction zones and are hence critical in the context of tectonics associated with convergent plate boundaries, and the evolution of continents. Several studies have also demonstrated that the transformation of lawsonite, a high-density hydrous mineral with $\mathrm{ca} .11 \mathrm{wt} \%$ $\mathrm{H}_{2} \mathrm{O}$ which is stable at high pressure and low temperature, from the lawsonite-stability to epidote-stability fields leads to the release of water in the subduction channel (e.g., Poli and Schmidt, 2002; Tsujimori et al, 2006). The presence of free water in the subduction channel triggers the partial melting of the mantle wedge above the subduction 
channel, and thus contributes to the generation of island arc volcanic rocks (Maruyama et al., 2009; Poli and Schmidt, 2002).

\section{Regional geology}

The southern Alaska convergent margin consists of several different tectonic units, including two elongate terranes - the Wrangellia composite terrane (consisting of the Peninsular, Wrangellia, and Alexander terranes), and farther outboard, the Chugach-Prince William terrane (Fig. 1). The Wrangellia composite terrane consists of Late Proterozoic and younger magmatic arc, oceanic plateau, rifted arc, and flysch belts (Plafker and Berg, 1994). During much of the Mesozoic, the Wrangellia and Chugach-Prince William terranes formed a magmatic arc and accretionary wedge, respectively, above a circum-Pacific subduction zone (e.g., Bradley et al., 2003; Kusky and Bradley, 1999; Kusky and Glass, 2007; Kusky et al., 1997a,b, 2003; Plafker et al., 1989). The boundary between the two terranes is the Border Ranges fault system, which apparently began its history as a subduction-related thrust system, and was later reactivated in many places as a strike slip fault system.

The accretionary wedge of south-central Alaska (Fig. 1) includes both Mesozoic and Cenozoic parts. The inboard, Mesozoic part has been referred to as the Chugach terrane and the outboard, Cenozoic part as the Prince William terrane (e.g., Coney et al., 1980). On the Kenai Peninsula, the farthest inboard rocks of the subduction complex belong to the Seldovia metamorphic complex (Bradley et al., 1997, 1999), which occupies a narrow fault slice just north of Seldovia village, whereas this structural position is occupied by the Liberty Creek schists in the northern Chugach Mountains. Metamorphism took place in the Early Jurassic (191-192 Ma) under conditions of high pressure and low temperature-conditions that suggest metamorphism in a subduction zone.

The McHugh Complex is a tectonic melange (Kusky and Bradley, 1999) that flanks the metamorphic rocks on their seaward side. Its main components are argillite, graywacke, chert, and basalt; minor components are limestone, gabbro, and ultramafic rocks, structurally juxtaposed at all scales (Bradley et al., 1999; Kusky and Bradley, 1999;
Kusky et al. (1997b) Prehnite-pumpellyite metamorphic facies assemblages are typical (Bradley et al., 1999). The primary melange foliation, ductile shear zones, and metamorphism are all suggested to have formed during subduction-accretion. The timing of subductionaccretion is not well known, but probably spanned much of the Jurassic and Cretaceous. Early Jurassic (191-192 Ma) metamorphism of the Seldovia metamorphic complex indicates subduction during that time. A Norian (230 Ma) age on gabbro of the Halibut Cove Complex is interpreted by Kusky and Glass (2007) to reflect formation in a suprasubduction zone spreading environment associated with early stages of subduction beneath Wrangellia. So although subduction probably was initiated in the Triassic, the subducting oceanic plate likely had Paleozoic crust.

The Valdez Group of Late Cretaceous (Campanian? to Maastrichtian) age flanks the McHugh Complex on its seaward side. It consists of medium- and thin-bedded graywacke turbidites, black argillite, and minor pebble to cobble conglomerate (Bradley et al., 1999). These strata were probably deposited on the downgoing plate in a deep-sea trench (Nilsen and Zuffa, 1982), and accreted shortly thereafter. The McHugh Complex was structurally emplaced above the Valdez Group along a thrust fault, known as the Chugach Bay thrust. Beneath the fault is a melange of partially to thoroughly disrupted Valdez Group turbidites (Kusky et al., 1997a,b).

The Border Ranges Fault forms the boundary between the Wrangellia Composite terrane and the Chugach-Prince William terranes. The Border Ranges fault has been suggested to have originated as a subduction thrust (Plafker and Berg, 1994; Plafker et al., 1989), but some critical data to test this idea is lacking (Pavlis and Roeske, 2007). However, the field relations on the Kenai Peninsula preclude the possibility that the present fault is merely a thrust that has been steepened to near vertical. For it to be a thrust, essentially unmetamorphosed, supracrustal rocks of the Wrangellia composite terrane in the hangingwall would somehow need to have been emplaced above deep-crustal blueschists in the footwall. It seems more likely that the fault that now bounds the Wrangellia composite terrane on the southeast is a latestage strike-slip or oblique-slip fault, as has been suggested, for example, along strike in the Matanuska Valley (Little and Naeser, 1989).

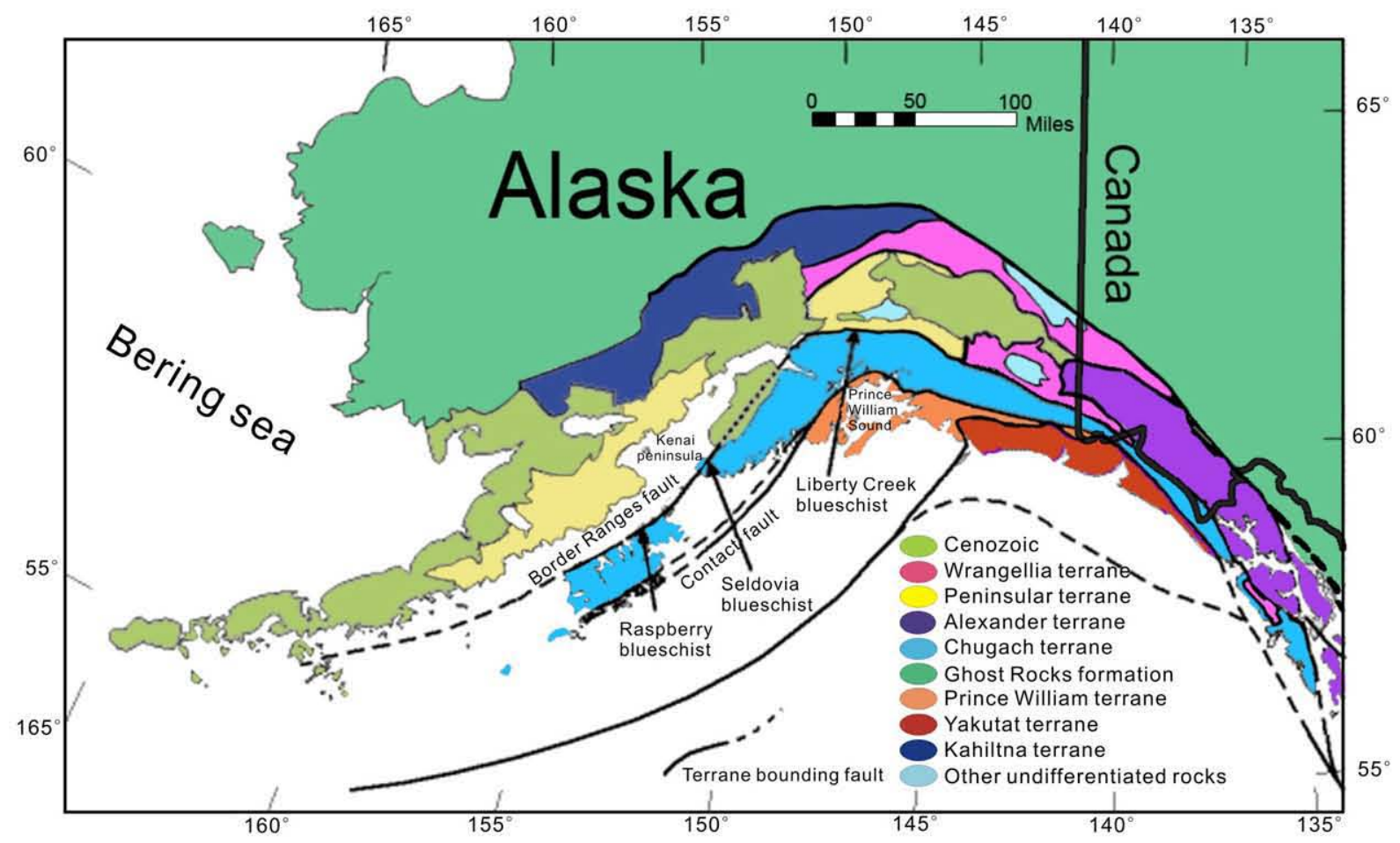

Fig. 1. Map of southern Alaska (modified alter Kusky et al., 1997a). 
The southern Alaska convergent margin contains several small belts of sedimentary and volcanic rocks metamorphosed to blueschist facies, located along the Border Ranges fault on the contact between the Wrangellia and Chugach terranes. These include the Raspberry Schist on Kodiak Afognak, Shuyak, and several small islands, the Seldovia blueschist on the Kenai Peninsula, and the Liberty Creek schist in the Chugach Mountains (Carden and Decker, 1977; Carden and Forbes, 1976; Roeske, 1986; Roeske et al., 1989). These belts are significant in that they are the most inboard, and thus probably contain the oldest record of Triassic-Jurassic northward-directed subduction beneath Wrangellia. Here we present a description of the structural, lithological, and petrological relationships in the Seldovia and Liberty Creek metamorphic belts, and discuss what these relationships might mean for the tectonic evolution and PT conditions during early stages of subduction along the southern Alaskan convergent margin.

\section{Field observations}

Several months of field work were carried out in the Seldovia and Liberty Creek blueschist belts to determine the main lithologies present and the structural history of the rock units. In this contribution we summarize this field work from both belts, then focus our petrological studies on the lawsonite and epidote blueschists from the Liberty Creek belt.

\subsection{Seldovia blueschist belt}

The Seldovia blueschist forms a narrow belt that is best exposed in and northwest of the village of Seldovia on the southern Kenai Peninsula (Fig. 2). Based on our mapping (Bradley et al., 1999, 2000) we subdivide the belt into three main lithological segments, including a fragmental volcaniclastic unit in the east (Fig. 3G-H), a metacarbonate unit in the west, and a mixed metapelitic and volcaniclastic unit between the two (Fig. 3A-C). The lithological descriptions in the following section follow a general north to south direction, starting at Outside Beach south of Seldovia Point, and continuing to the village of Seldovia. Important locations are noted on Fig. 2.

\subsubsection{Description of rock exposures}

3.1.1.1. Outside Beach, north end. Outcrops at Outside Beach north of Seldovia include, from south to north (1) graywacke blocks in argillite matrix; (2) basalt; and (3) radiolarian chert (Figs. 2 and 3E-F) belonging to the McHugh Complex. About $300 \mathrm{~m}$ north along the beach, a prominent seastack exposes an argillite-matrix melange containing blocks of greenstone, limestone, pebbly graywacke, and chert. This particular limestone is undated but is typical of the limestone blocks in the McHugh Complex that have yielded Permian fossils of Tethyan affinity (Bradley et al., 1999). Still farther north, at the beginning of a long section of cliffs that continues to the end of the beach, is a belt of melange containing blocks of sandstone and pebbly sandstone that are reminiscent of the Valdez Group (moderately sorted, dominant quartz and feldspar framework grains), and quite different from typical sandstones of the McHugh Complex (poorly sorted, matrix-rich, dominant chert and volcanic framework grains). This resemblance suggests that these blocks and their matrix might have been injected upward along a fault zone from underthrust Valdez Group rocks (Fig. 3D).

3.1.1.2. Outside Beach, south end. High-pressure metamorphic rocks of the Seldovia blueschist belt stretch from the southern end of Outside Beach to Watch Point in Seldovia, a linear distance of about $1.5 \mathrm{~km}$. A variety of metamorphic rocks are exposed, including greenstone (metamorphosed basalt and associated volcaniclastic rocks), schist (metamorphosed pelite), thin-bedded quartzite (metachert), and marble. Various types of schists include common biotite-amphibole schist, epidote-chlorite-albite schist, glaucophane/riebeckite-epidote-chlorite blueschist, and blue-green hornblende-garnet-epidote schist. The various rock types are typically separated by steep faults. Throughout the Seldovia blueschist belt small-scale structures include superb early intrafolial folds, later tight to isoclinal folds, strong mineral and intersection lineations, kink bands, and late sulfide-rich shear zones, and even later brittle fault zones. Hornblende and white mica separates from two schist samples have yielded ${ }^{40} \mathrm{Ar} /{ }^{39} \mathrm{Ar}$ plateau ages of 191-192 Ma (Fig. 4: A. Till, pers. Comm). This age falls in the Early Jurassic (Pliensbachian according to the DNAG time scale) and, as noted previously, is believed to date subduction zone metamorphism.

Between Outside Beach and the marble quarry there is an interesting wave-washed outcrop best viewed at low-tide, and during calm-water conditions. At this outcrop the fragmental nature of one of the distinctive units in the blueschist belt can be observed. The layers in the metamorphic rocks here are very flattened defining the foliation, and the protolith is questionable. In some places, the fragments resemble volcaniclastic conglomerate clasts (or perhaps pillow breccia), whereas in other places the apparently fragmental nature of the outcrop can be ascribed to dismemberment of isoclinal folds. There are some obvious fold hinges here, and we favor an origin by early isoclinal folding of a volcaniclastic conglomerate/sandstone unit, similar to units in the McHugh Complex, and in less-deformed parts of the Seldovia blueschist belt. Excellent examples of less-deformed volcaniclastic conglomerate are present in coastal exposures north of Watch Point.

3.1.1.3. Marble quarry. The old marble quarry is unfortunately mostly filled in, but numerous blocks and a few outcrops showing interesting structures and minerals remain. There are bright green (fuchsitic?) micas, chloritized garnets with beautiful pressure shadows, and infolded graphitic (carbonaceous) schist and layers of amphibolite still visible. The foliation in the metapelite and metabasite layers is clearly folded, whereas the marble shows evidence for grain-scale recrystallization and polyphase folding. A late stylolitic cleavage truncates both F1 and F2 folds.

3.1.1.4. Gray Cliff. Further southwest at Gray Cliff, units of limestone and dolostone are interlayered, and are in fault contact with adjacent metabasite and interlayered quartzites (recrystallized chert?). Just south of Gray Cliff, beautiful quartz-garnet-mica schists display tight to isoclinal folds, and are cut by late brittle faults.

\subsubsection{Structural synthesis of Seldovia blueschist belt}

Detailed observations of outcrops of the Seldovia blueschist belt has enabled us to construct a structural history of the belt. Beds and foliations strike to the northeast, generally parallel to the belt, and most mineral lineations plunge moderately to the northeast (Fig. 2). Rocks of the metamorphic terrane preserve numerous folds. Many of these contain limited information on ages, but in some cases fold overprinting relationships have enabled us to establish the geometry and style of F1 and F2 structures. F1 folds are tight to isoclinal structures, some of which form intrafolial relationships with the main foliation. $F 1$ folds are nearly all northeast striking with moderately to steeply NE plunging hinges (parallel to the main mineral lineation), although a rare NW striking F1 fold was noted. In the marble quarry, F1 folds are also NE striking, but have south to southwest plunging hinges (Fig. 2).

F2 folds are more open to tight structures, with north-northeast to north-northwest striking axial surfaces, and northeast plunging hinges (also parallel to the mineral lineation). In the marble quarry, F2 folds strike northeast and have gently southwest plunging hinges (Fig. 2).

Unclassified folds (Fig. 2), whose generation could not be established, strike northeast and have generally shallow NE or SW plunging hinges.

In addition to the fold overprinting relationships, we were able to establish that the main tectonic foliation is cut by kink bands, and by 


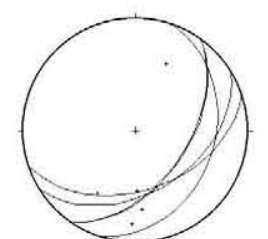

Seldovia marble quarry F1.folds A.P and hinges

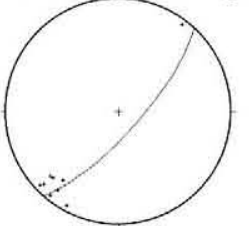

Seldovia marble quarry F2.folds A.P and hinges

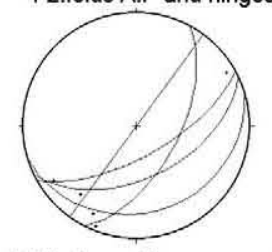

Seldovia marble quarry unclassified folds A.P and contoured(with data plotted) and hinges

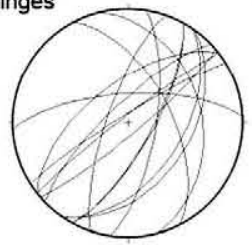

beds

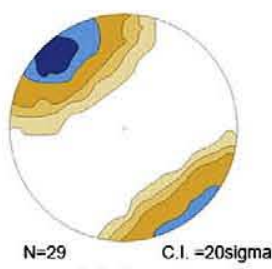
foliations

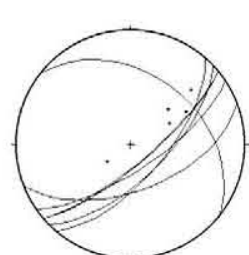

F1.folds A.P and hinge

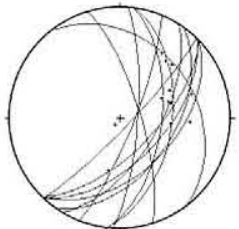

F2.folds A.P and hinges

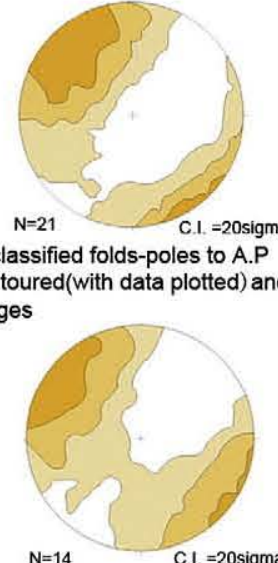

beds

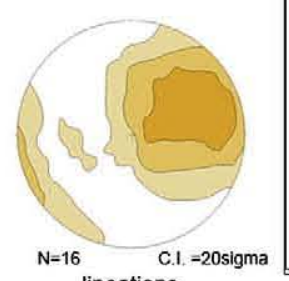

lineations
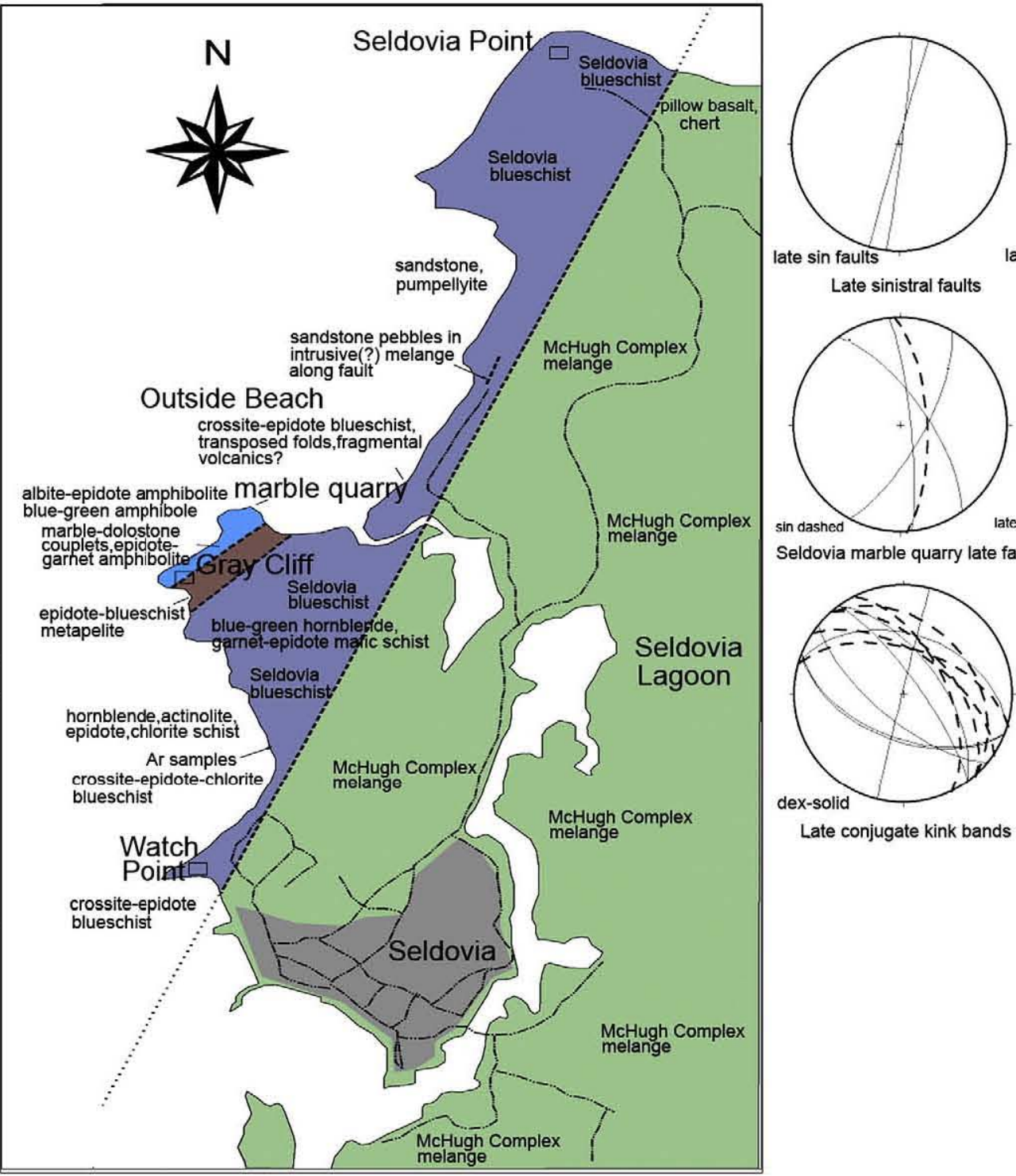

late $\sin$ faults

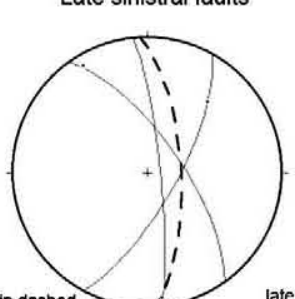

Seldovia marble quarry late faults

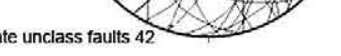

Late unclassified faults

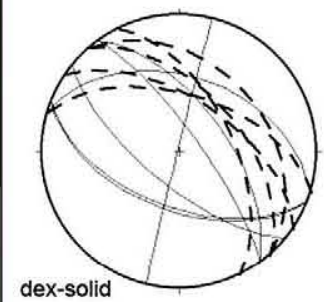

Late conjugate kink bands

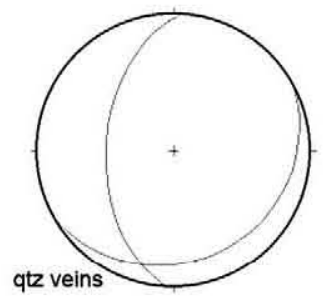

Late quartz veins

Fig. 2. Detailed map of Seldovia schist (after Bradley et al., 2000). Stereoplots of beds, foliations, lineations, fold and late fault data from the Seldovia schist are shown. 

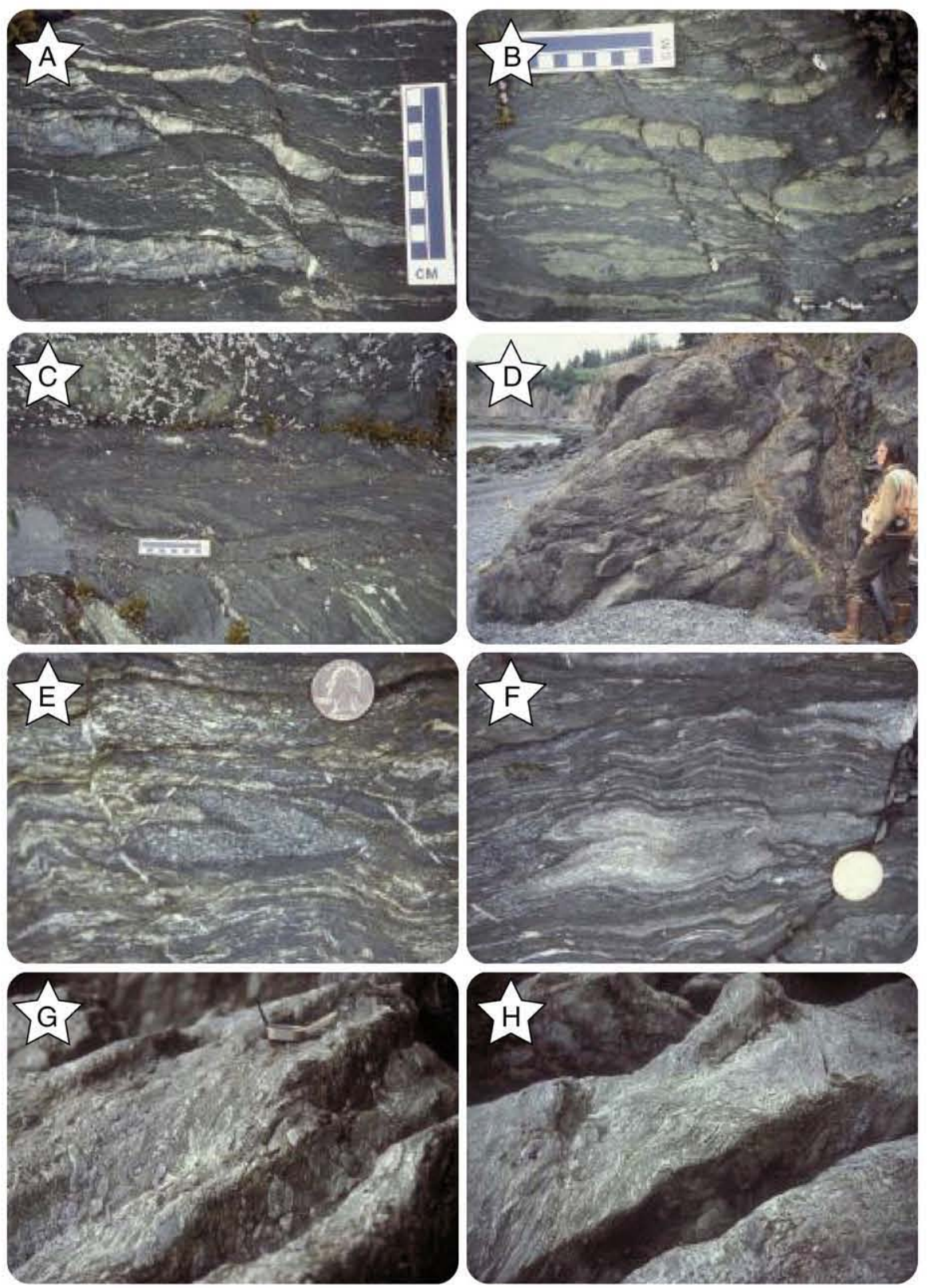

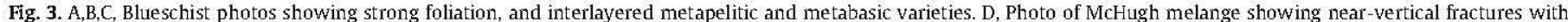
clasts of sandstone along the fractures. E-F, photos of intrafolial folds from Outside Beach. G-H, photos of fragmental Rocks, see text for discussion.

late faults and cataclastic fault zones. Late sulfide-rich shear zones also truncate the tectonic foliation and the kink bands, and further north in the Chugach terrane we were able to date similar structures, and correlate them with a period of faulting and mineralization associated with Paleocene passage of a triple junction along the southern margin of the Chugach-Prince William terrane (Bradley et al., 2003; Kusky et al., 1997a, 2003).

\subsection{Liberty Creek schist}

In the northern Chugach Mountains, the Liberty Creek schist forms the oldest and most landward portion of the Chugach terrane. It is composed of very fine-grained blueschist and greenschist derived from argillite and mafic tuff, and lesser mafic flows (Fig. 5). The Liberty Creek schist forms a narrow, fault-bounded slab, about $13 \mathrm{~km}$ wide in a north-south direction, and about $28 \mathrm{~km}$ long in an eastwest direction, and is correlated with the high- $P / T$ Seldovia blueschist belt on the Kenai Peninsula and the high-P/T Raspberry schist on
Kodiak Island. The protolith age of the Liberty Creek schist is pre-Early Cretaceous, based on the oldest $\mathrm{K}-\mathrm{Ar}$ whole rock apparent age for the schists (Plafker et al., 1989) and may be pre-Middle Jurassic, which is the $\mathrm{Ar} / \mathrm{Ar}$ age of metamorphism of the correlative (?) blueschist of Iceberg Lake (Sisson and Onstott, 1986).

The Libert Creek schist is bordered on the north by the highly deformed and metamorphosed Haley Creek assemblage (Fig. 5), interpreted as the southern margin of the Wrangellia terrane. The Haley Creek metamorphic complex was thrust at least $40 \mathrm{~km}$ southward onto the northern Chugach terrane, forming a large outlying nappe to the south of the Liberty Creek schist in the area of Fig. 5. The Haley Creek metamorphic complex is composed of two units. An older unit, the Strelna Formation, consists of highly deformed and metamorphosed metasedimentary and metavolcanic rocks that are, at least in part, of Early Pennsylvanian age. The other younger unit, the Uranatina River metaplutonic assemblage, consists of highly deformed and metamorphosed gabbro, diorite, tonalite and granodiorite and trondhjemite of Middle Pennsylvanian and Late Jurassic age. A U-Pb sphene age of 

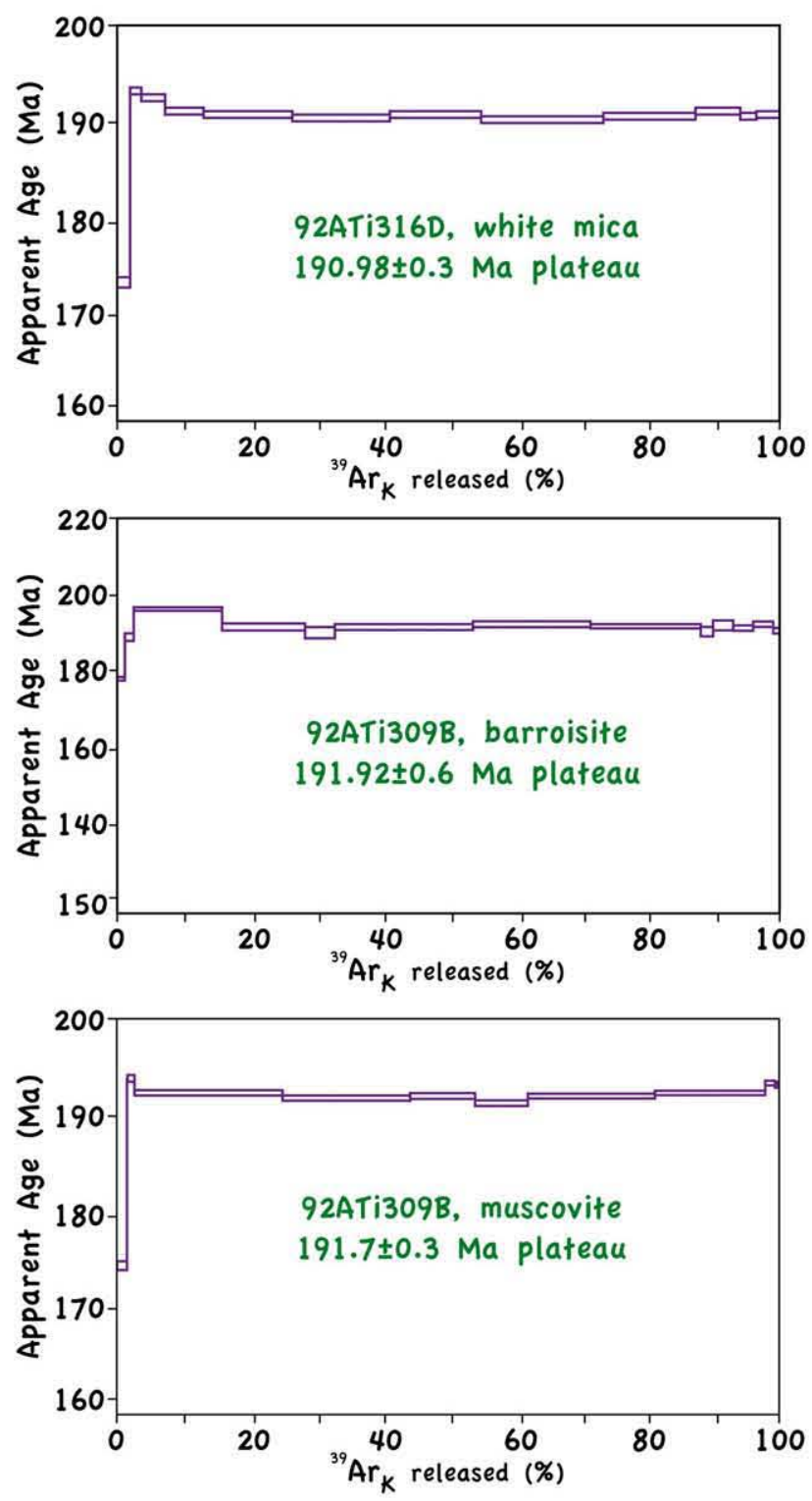

Fig. 4. Ar-Ar plateaus from the Seldovia schist, provided by A. Till (USGS).

156 Ma for a Pennsylvanian metaganodiorite and $\mathrm{U}-\mathrm{Pb}$ zircon age of $153 \mathrm{Ma}$ for a schistose granodiorite, indicate that Uranatina River metaplutonic rocks intruded the Late Jurassic Tonsina magmatic arc. The strong linear fabric and the increase of metamorphic grade, to upper amphiboltie facies near the Uranatina River metaplutonic assemblage, indicate Late Jurassic syntectonic intrusion of these plutons.

The Liberty Creek schists are transitional blueschist to greenschist grade metamorphic rocks that crop out along the northern edge of Chugach terrane adjacent to the Border Ranges fault. The blueschist belt is bounded by the Tonsina ultramafic complex to the northwest (Fig. 5), the oblique dextral-thrust Second Lake fault to the south and Taral fault (outside of map in Fig. 5) to the east (Nokleberg et al., 1994). Reconnaissance studies by Plafker and Berg (1994) and our own mapping reveal that rock types include blueschist, greenschist, muscovite and actinolite schist, siliceous schist, metachert, metabasalt, and graphitic schist. In some places units reveal compositional layering defined by chlorite, feldspar, actinolite, epidote, and crosstie rich layers. The protolith was mostly basaltic pillow flows, tuffs, tuff breccias, and volcaniclastic rocks with minor chert, carbonate, and argillaceous rocks; some faint primary structures at Liberty Creek suggest a breccia or pillow breccia origin, similar to the exposures in the Seldovia blueschist

belt. Very fine-grained blue amphibole, mostly glaucophane/riebeckite with rarely occurring lawsonite, occurs at some levels. The protolith age is pre-early Cretaceous based on $\mathrm{K}$-Ar whole rock analysis (Plafker et al., 1989). Early Cretaceous (123-107 Ma) K-Ar whole rock ages have been determined from Liberty Creek but these ages are uncertain due to fine grain size of the amphiboles. The geochemistry of the metabasalts in the Liberty Creek are N type MORB (Plafker et al., 1989).

The Liberty Creek schist is poly-deformed (Fig. 5). Well-developed foliation has variable dips ranging from gently to the northwest, to steeply west and northeast, with SE and NW trending mineral lineations (Fig. 5a,b). At least two generations of folds exist in the Liberty Creek Schist. The first generation folds are mostly symmetrical, 5$20 \mathrm{~cm}$ in size and tight to isoclinal with axial planar foliation parallel to the main foliation in the unit. A few of these folds show asymmetry to south. The second generation folds are upright E-W trending crenulation folds, locally showing a northward vergence. All these structures are truncated by Cenozoic brittle faults (Fig. 5c) that create very prominent, steeply dipping fracture surfaces (Nokleberg et al., 1989), striking mostly the NW.

In this study, samples were collected during mapping of the Liberty Creek blueschist. We selected one outcrop (Fig. 5) for detailed petrologic study, based on the presence of well-preserved blueschist facies minerals, and a variety of protoliths.

\section{Metamorphic evolution}

\subsection{Petrography and mineral chemistry}

We classified the Liberty Creek schists into two types based on their mineral parageneis: (1) lawsonite blueschists (LBS, sample 110.430); and (2) epidote blueschists (EBS, samples 110.431, 110.432, 110.433 and 110.434). The LBS are metapelites and contain lawsonite + phengite + chlorite + titanite + albite \pm apatite \pm carbonates and quartz. The EBS comprises both metapelites and metabasites with basaltic composition (Table 5, Plafker and Berg, 1994). The metapelites contain epidote + phengite + chlorite + albite + titanite \pm carbonates and quartz. The metabasites are composed of Na-amphiboles (Mgriebeckite), $\mathrm{Na}-\mathrm{Ca}$ amphiboles (winchite), and $\mathrm{Ca}$-amphiboles (Fehornblende, Fe-Tsermackite and actinolite) + epidote + phengite + chlorite + albite + titanite + magnetite + carbonates and quartz (Fig. 6).

These rocks are intensely foliated. The texture varies from lepidoblastic in the metapelitic samples, defined by preferred orientation of phengite and chlorite (samples 110.430 and 110.434; Fig. 7.1-8), to nematoblastic or nemato-lepidoblastic in the metabasite sample 110.431 where the orientation is marked by amphiboles and chlorites (Fig. 7C, D). The texture in samples $110.432-110.433$ is grano-lepidoblastic (Fig. 7A, E). The regional foliation is locally transitional to mylonite (Fig. 7.1, 4).

Chemical analyses of the major minerals in five representative samples were carried out with a JEOL-Superprobe JXA-8900M microprobe equipped with five spectrometers at the Luis Bru Electronic Microscopy Centre (Universidad Complutense de Madrid). The operating parameters were: $15 \mathrm{kV}$ accelerating voltage, $20 \mathrm{nA}$ beam current, between 1 and $5 \mu \mathrm{m}$ of beam diameter and 10 s counting time. Some of the microprobe analyses do not show the ideal total probably due to the small grain size of the samples, which forced us to use a $1 \mu \mathrm{m}$ beam diameter. In these conditions, a small part of elements such as $\mathrm{Na}_{2} \mathrm{O}$ may escape making the sum of the corresponding phases slightly lower than normal. Representative mineral compositions are listed in Tables 1-4. Mineral abbreviations in all figures and tables are after Kretz (1983) and Holland and Powell (1998).

\subsubsection{Phengites}

Phengite is present in both EBS and LBS. It is fine-grained, up to $0.5 \mathrm{~mm}$ long and tends to grow as orientated lepidoblasts in the 

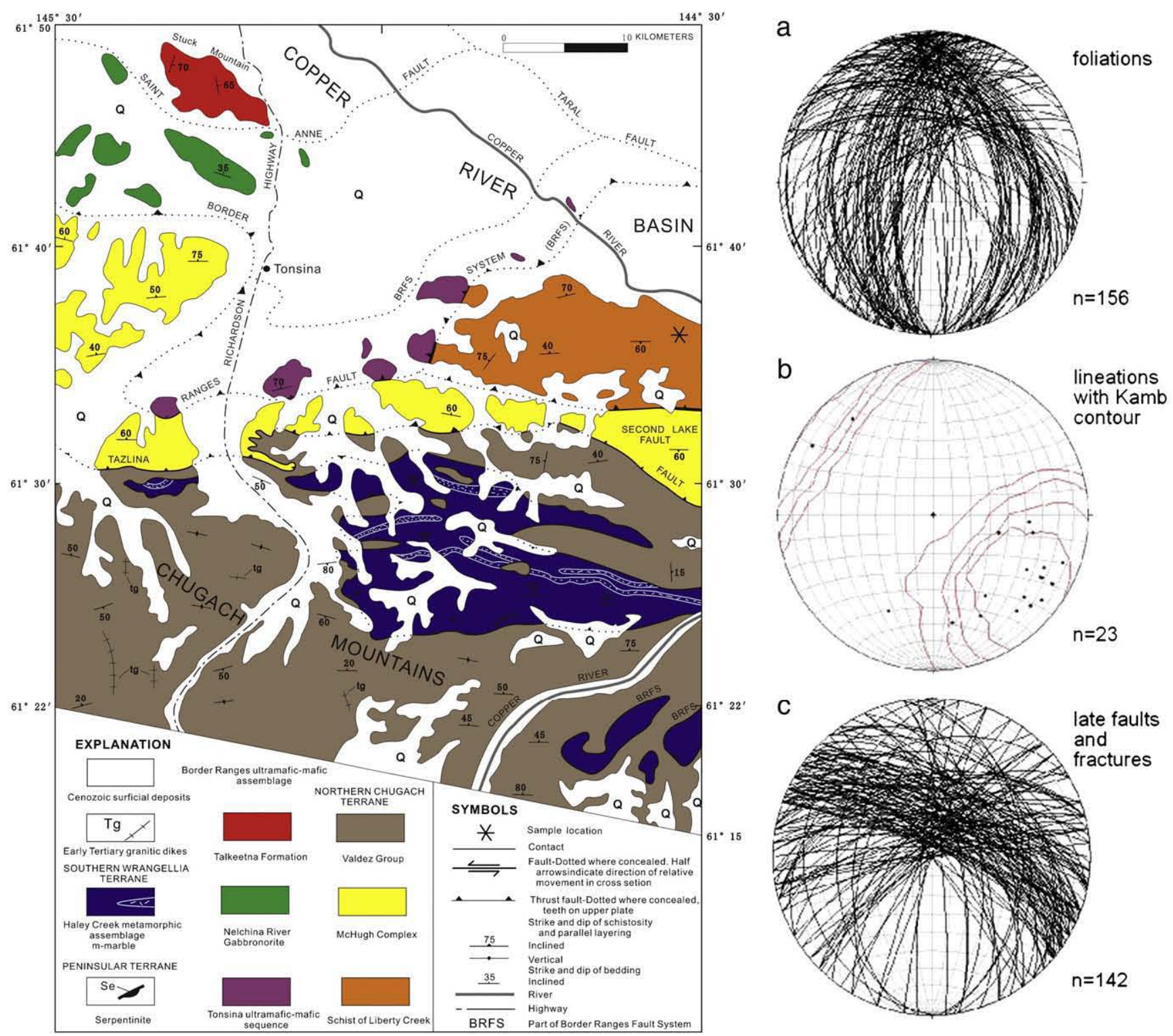

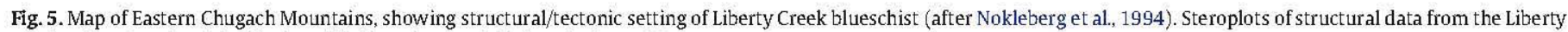
Creek schist showing (a) foliations, (b) lineations, and (c) late faults and fractures.

matrix (Fig. 7.5-8 and H), rarely tabular in shape (Fig. 7.5, 6). It is well oriented defining the foliation together with the chlorite in all samples. The silica content in the phengites is relatively high, ranging between 3.18 and 3.58 c.p.f.u. (calculated on the basis of 11 oxygens). $\mathrm{X}_{\mathrm{Mg}}$ varies among the different samples with $\mathrm{X}_{\mathrm{Mg}} \approx 0.64-0.67$ in LBS and $\mathrm{X}_{\mathrm{Mg}} 0.85-0.88$ in EBS (Fig. 8A, Tables 1-4). Na contents are very low (Fig. 8D), reaching the maximum in LBS (sample 110.430). The ratio $\mathrm{Na} /(\mathrm{Na}+\mathrm{K})$ is 0.02 in LBS and up to 0.01 in EBS (Tables 1-4). All phengite compositions plot below the Tschermak substitution line (Fig. $8 \mathrm{C}$ ), indicating that part of the $\mathrm{Fe}$ is in a trivalent state, being substituted by $\mathrm{Al}$. In the diagram $\mathrm{FeO}_{\mathrm{T}}-\mathrm{Al}_{2} \mathrm{O}_{3}$ (Fig. 8B), all the white micas are classified as metamorphic micas from glaucophane schists (Miyashiro, 1973).

\subsubsection{Amphibole}

Amphiboles are present only in the mafic schists (samples 110.432-433). The composition of blue amphibole in the Libery Creek rocks is $\mathrm{Mg}$-riebeckite with a $\mathrm{X}_{\mathrm{Al}}=\mathrm{Al} /\left(\mathrm{Al}+\mathrm{Fe}^{3+}\right)$ ranging from 0.36 (samples 110.432-110.433) up to 0.50 (sample 110.431) and a $\mathrm{X}_{\mathrm{Mg}}=\mathrm{Mg} /\left(\mathrm{Mg}+\mathrm{Fe}^{2+}\right)$ that varies from 0.57 up to 0.75 , respectively

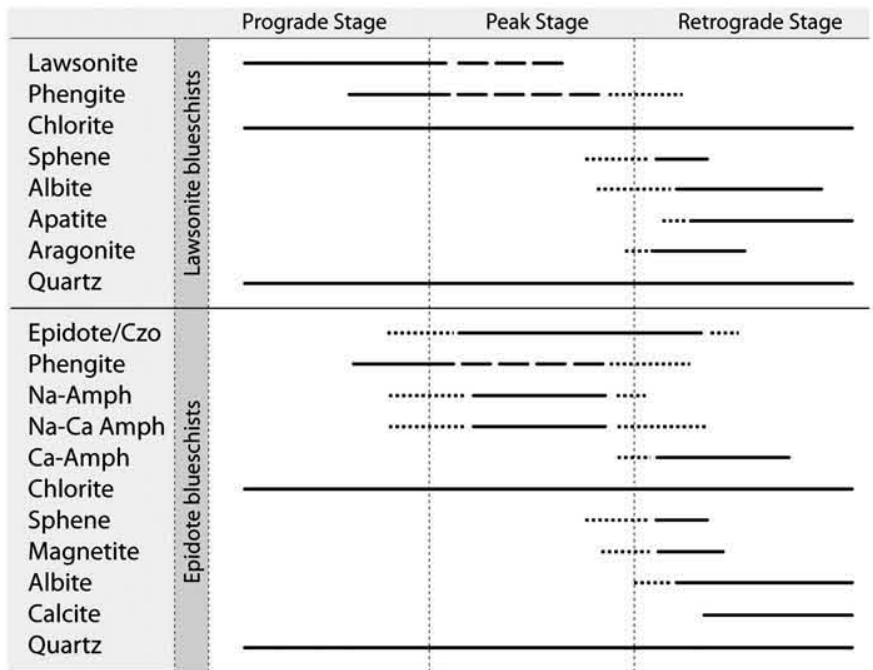

Fig. 6. Phase crystallization diagram showing the mineral stability along the metamorphic path of the Liberty Creek Schists. 

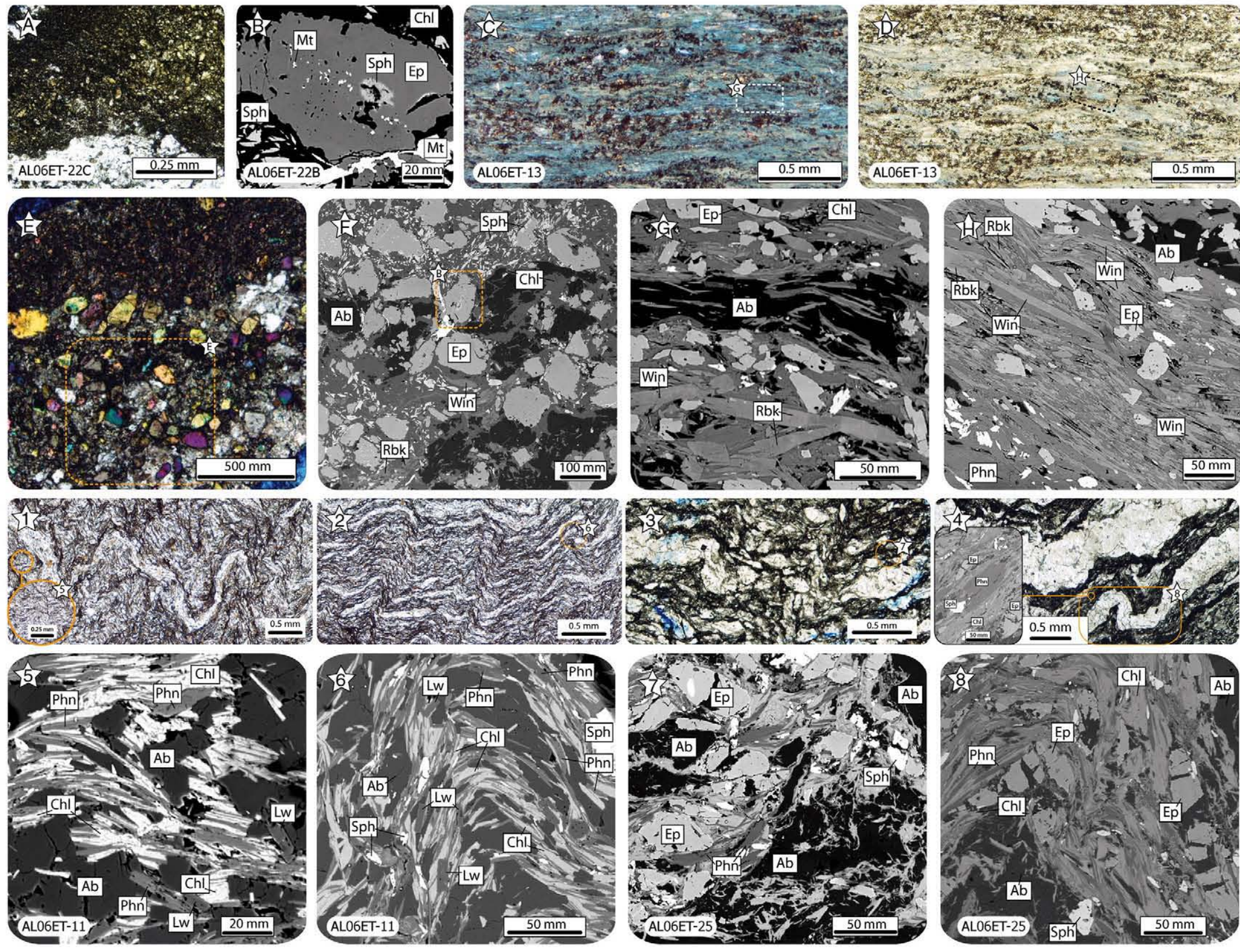

Fig. 7. 1-8, Microphotographs of the Liberty Creek pelitic Schist. 1-2 and 5-6 are lawsonite blueschists at different scales: 3-4 and 7-8 are epidote blueschists: sample location in Figs. 1 and 5. 1-4, thin section images showing the lepidoblastic texture and the highly deformed fabric. 5-8, corresponding EMP images inquiring some details of the Lw-deformed rhombs (5 and 6 ), and the late-Ab porphyroblasts growth. Lw: lawsonite; Ep: epidote; Phn: phengite; Chl: chlorite; Ab: albite; Sph: sphene. A-H, Microphotographs of the Liberty Creek mafic Schist at different scales; sample location in Figs. 1 and 5. A, E and F show the granoblastic texture defined by the abundant allotriomorphic epidote grains. B shows the magnetite inclusions in a corroded epidote crystal. C and D are thin section images showing the nematoblastic texture and the intensely deformed foliation. $\mathrm{G}$ and $\mathrm{H}$ are the corresponding EMP images. Win: winchite; Rbk: riebeckite; Ep: epidote; Chl: chlorite; Ab: albite; Sph: sphene; Mt: magnetite. 
Table 1

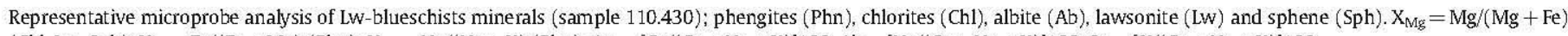
$(\mathrm{Chl}, \mathrm{Lw}, \mathrm{Sph}) ; \mathrm{X}_{\mathrm{Fe}}=\mathrm{Fe} /(\mathrm{Fe}+\mathrm{Mg})(\mathrm{Phn}) ; \mathrm{X}_{\mathrm{Na}}=\mathrm{Na} /(\mathrm{Na}+\mathrm{K})(\mathrm{Phn}) ; \mathrm{An}=[\mathrm{Ca} /(\mathrm{Ca}+\mathrm{Na}+\mathrm{K})] 100, \mathrm{Ab}=[\mathrm{Na} /(\mathrm{Ca}+\mathrm{Na}+\mathrm{K})] 100, \mathrm{Or}=[\mathrm{K} /(\mathrm{Ca}+\mathrm{Na}+\mathrm{K})] 100$.

\begin{tabular}{|c|c|c|c|c|c|c|c|c|c|c|c|c|}
\hline \multirow{2}{*}{$\frac{\text { Sample }}{\text { Mineral }}$} & \multicolumn{12}{|c|}{110,430} \\
\hline & \multirow{2}{*}{$\frac{\text { Phn }}{5-4}$} & \multirow{2}{*}{$\frac{\mathrm{Phn}}{4}$} & \multirow{2}{*}{$\frac{\mathrm{Chl}}{2}$} & \multirow{2}{*}{$\frac{\text { Chl }}{71}$} & \multirow{2}{*}{$\frac{\text { Ch1 }}{31}$} & \multirow{2}{*}{$\frac{\mathrm{Chl}}{32}$} & \multirow{2}{*}{$\frac{\mathrm{Ab}}{6}$} & \multirow{2}{*}{$\frac{\mathrm{Ab}}{3}$} & \multirow{2}{*}{$\frac{L w}{5-3}$} & \multirow{2}{*}{$\frac{\mathrm{LW}}{16}$} & \multirow{2}{*}{$\frac{\text { Sph }}{13}$} & \multirow{2}{*}{$\frac{\text { Sph }}{4}$} \\
\hline Analysis & & & & & & & & & & & & \\
\hline $\mathrm{SiO}_{2}$ & 53.21 & 50.26 & 25.98 & 25.41 & 32.11 & 30.25 & 66.02 & 64.75 & 39.02 & 37.71 & 33.14 & 30.54 \\
\hline $\mathrm{TiO}_{2}$ & 0.03 & 0.10 & 0.01 & 0.01 & 0.03 & 0.04 & 0.08 & 0.06 & 0.13 & 0.20 & 33.55 & 37.04 \\
\hline $\mathrm{Al}_{2} \mathrm{O}_{3}$ & 25.90 & 28.08 & 21.53 & 20.62 & 19.69 & 23.03 & 20.25 & 21.51 & 30.54 & 30.51 & 3.33 & 2.17 \\
\hline $\mathrm{Cr}_{2} \mathrm{O}_{3}$ & 0.00 & 0.01 & 0.04 & 0.06 & 0.07 & 0.00 & 0.05 & 0.03 & 0.05 & 0.03 & 0.00 & 0.00 \\
\hline $\mathrm{Fe}_{2} \mathrm{O}_{3}$ & 0.00 & 0.01 & 0.00 & 0.00 & 0.00 & 0.00 & 0.87 & 1.06 & 0.00 & 0.00 & 0.00 & 0.00 \\
\hline $\mathrm{FeO}$ & 2.39 & 2.65 & 27.01 & 26.93 & 23.94 & 20.41 & 0.00 & 0.00 & 0.25 & 2.75 & 0.27 & 0.35 \\
\hline MnO & 0.00 & 0.04 & 0.10 & 0.46 & 0.37 & 0.4 & 0.02 & 0.00 & 0.00 & 0.09 & 0.00 & 0.00 \\
\hline MgO & 2.75 & 2.71 & 11.79 & 12.18 & 10.28 & 9.24 & 0.49 & 0.78 & 0.07 & 0.91 & 0.04 & 0.02 \\
\hline $\mathrm{CaO}$ & 0.00 & 0.00 & 0.02 & 0.01 & 0.03 & 0.01 & 0.04 & 0.01 & 16.38 & 14.98 & 26.13 & 28.11 \\
\hline $\mathrm{Na}_{2} \mathrm{O}$ & 0.13 & 0.16 & 0.01 & 0.02 & 0.02 & 0.07 & 10.73 & 8.10 & 0.42 & 0.04 & 0.06 & 0.01 \\
\hline $\mathrm{K}_{2} \mathrm{O}$ & 9.52 & 9.99 & 0.08 & 0.01 & 0.44 & 3.03 & 0.59 & 2.93 & 0.19 & 0.20 & 0.16 & 0.12 \\
\hline Total & 93.93 & 94.01 & 86.57 & 85.71 & 86.97 & 86.48 & 99.14 & 99.23 & 87.03 & 87.40 & 96.67 & 98.35 \\
\hline \multicolumn{13}{|c|}{ Data calculated with AX software (Holland and Powell, 1998) } \\
\hline $\mathrm{Si}$ & 3.56 & 3.39 & 2.79 & 2.77 & 3.33 & 3.15 & 2.93 & 2.88 & 2.59 & 2.52 & 1.10 & 1.01 \\
\hline $\mathrm{Ti}$ & 0.00 & 0.01 & 0.00 & 0.00 & 0.00 & 0.00 & 0.00 & 0.00 & 0.01 & 0.01 & 0.84 & 0.92 \\
\hline Al & 2.04 & 2.23 & 2.72 & 2.65 & 2.40 & 2.83 & 1.06 & 1.13 & 2.39 & 2.40 & 0.13 & 0.08 \\
\hline $\mathrm{Cr}$ & 0.00 & 0.00 & 0.00 & 0.01 & 0.01 & 0.00 & 0.00 & 0.00 & 0.00 & 0.00 & 0.00 & 0.00 \\
\hline $\mathrm{Fe}^{3+}$ & 0.00 & 0.00 & 0.00 & 0.00 & 0.00 & 0.00 & 0.03 & 0.04 & 0.00 & 0.00 & 0.00 & 0.00 \\
\hline $\mathrm{Fe}^{2+}$ & 0.13 & 0.15 & 2.43 & 2.45 & 2.07 & 1.78 & 0.00 & 0.00 & 0.01 & 0.15 & 0.01 & 0.01 \\
\hline $\mathrm{Mn}$ & 0.00 & 0.00 & 0.01 & 0.04 & 0.03 & 0.04 & 0.00 & 0.00 & 0.00 & 0.00 & 0.00 & 0.00 \\
\hline $\mathrm{Mg}$ & 0.27 & 0.27 & 1.89 & 1.98 & 1.59 & 1.43 & 0.03 & 0.05 & 0.01 & 0.09 & 0.00 & 0.00 \\
\hline $\mathrm{Ca}$ & 0.00 & 0.00 & 0.00 & 0.00 & 0.00 & 0.00 & 0.00 & 0.00 & 1.16 & 1.07 & 0.93 & 1.00 \\
\hline $\mathrm{Na}$ & 0.02 & 0.02 & 0.00 & 0.00 & 0.00 & 0.01 & 0.92 & 0.70 & 0.05 & 0.00 & 0.00 & 0.00 \\
\hline $\mathrm{K}$ & 0.81 & 0.86 & 0.01 & 0.00 & 0.06 & 0.40 & 0.03 & 0.17 & 0.02 & 0.02 & 0.01 & 0.01 \\
\hline $\mathrm{X}_{\mathrm{Mg}}$ & & & 0.44 & 0.45 & 0.43 & 0.45 & & & 0.33 & 0.37 & 0.21 & 0.10 \\
\hline $\mathrm{X}_{\mathrm{Na}}$ & 0.02 & 0.02 & & & & & & & & & & \\
\hline $\mathrm{X}_{\mathrm{Fe}}$ & 0.33 & 0.36 & & & & & & & & & & \\
\hline An & & & & & & & 0.21 & 0.00 & & & & \\
\hline $\mathrm{Ab}$ & & & & & & & 96.24 & 80.72 & & & & \\
\hline Or & & & & & & & 3.55 & 19.28 & & & & \\
\hline
\end{tabular}

A

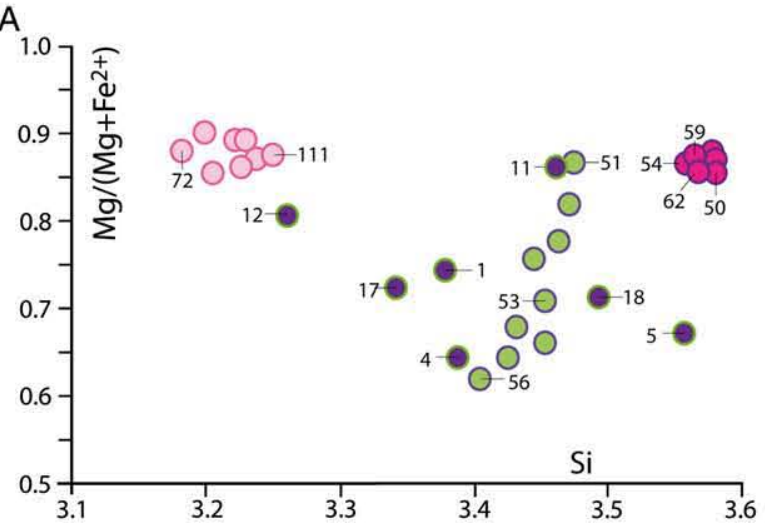

B

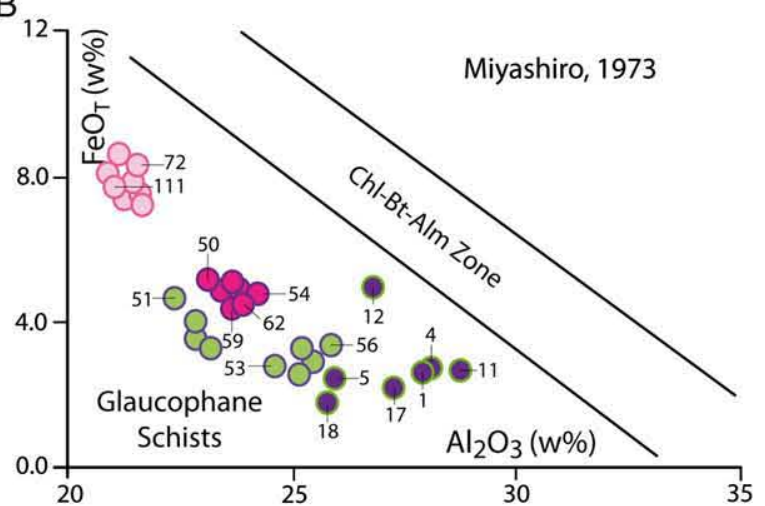

$\mathrm{D}$

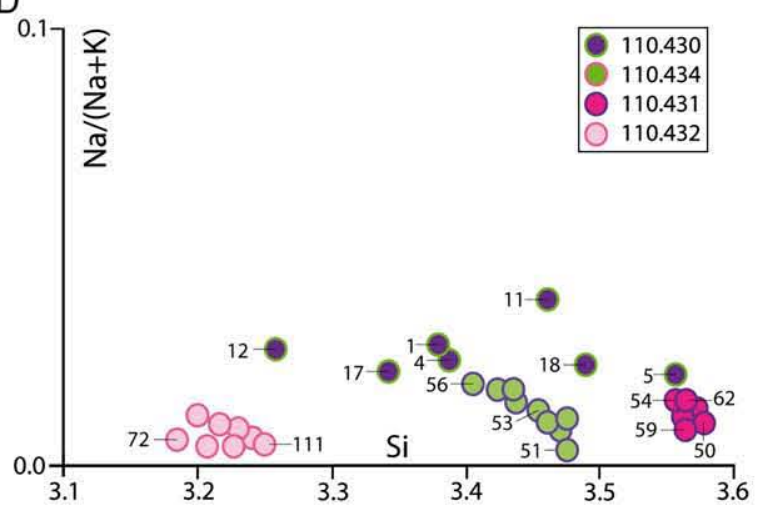

C

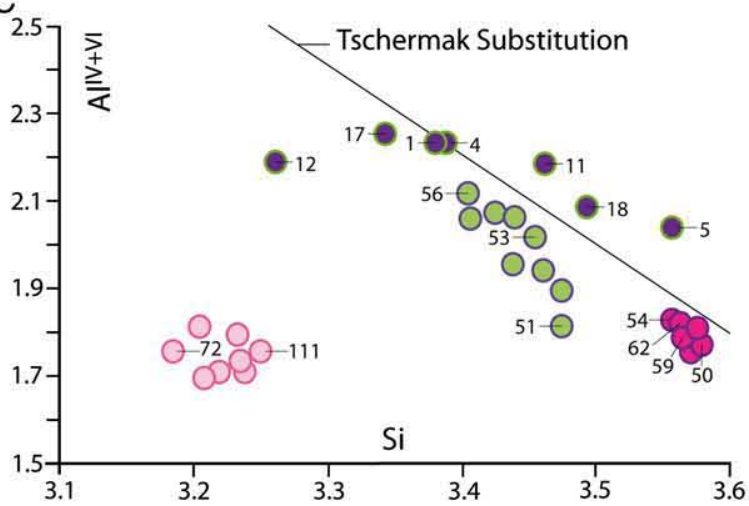

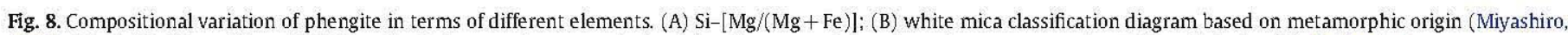
1973); (C) Si-[Na/(Na + K)] and (D) Si vs. $\mathrm{Al}_{\mathrm{T}}$. Cation numbers are calculated for 11 oxygens. Pointed numbers correspond to EMP analysis listed in Tables $1-4$. 
Table 2

Representative microprobe analysis of Ep-blueschists minerals (sample 110.434); phengites (Phn), chlorites (Chl), albite ( $\mathrm{Ab}$ ), clinozoisite (Czo), calcite (Cc) and sphene $(\mathrm{Sph}) \cdot \mathrm{X}_{\mathrm{Mg}}=\mathrm{Mg} /(\mathrm{Mg}+\mathrm{Fe})(\mathrm{Chl}, \mathrm{Sph}) ; \mathrm{X}_{\mathrm{Fe}}=\mathrm{Fe} /(\mathrm{Fe}+\mathrm{Mg})(\mathrm{Phn}) ; \mathrm{X}_{\mathrm{Fe}}=\mathrm{Fe}^{3+} /\left(\mathrm{Fe}^{3+}+\mathrm{Al}\right)$ $(\mathrm{Czo}) ; \mathrm{X}_{\mathrm{Na}}=\mathrm{Na} /(\mathrm{Na}+\mathrm{K})(\mathrm{Phn}) ; \mathrm{An}=[\mathrm{Ca} /(\mathrm{Ca}+\mathrm{Na}+\mathrm{K})] 100, \mathrm{Ab}=[\mathrm{Na} /(\mathrm{Ca}+\mathrm{Na}+\mathrm{K})]$ 100, Or $=[\mathrm{K} /(\mathrm{Ca}+\mathrm{Na}+\mathrm{K})] 100$.

\begin{tabular}{|c|c|c|c|c|c|c|c|c|}
\hline \multirow{2}{*}{$\frac{\text { Sample }}{\text { Mineral }}$} & \multicolumn{8}{|c|}{110,434} \\
\hline & \multirow{2}{*}{$\frac{P h n}{51}$} & \multirow{2}{*}{$\frac{\text { Phn }}{53}$} & \multirow{2}{*}{$\frac{P h n}{56}$} & \multirow{2}{*}{$\frac{\mathrm{Czo}}{54}$} & \multirow{2}{*}{$\frac{\text { Chl }}{52}$} & \multirow{2}{*}{$\frac{\mathrm{Ab}}{69}$} & \multirow{2}{*}{$\frac{C c}{71}$} & \multirow{2}{*}{$\frac{\text { Sph }}{58}$} \\
\hline Analysis & & & & & & & & \\
\hline $\mathrm{SiO}_{2}$ & 50.26 & 49.57 & 49.02 & 38.05 & 27.00 & 68.62 & 0.00 & 30.22 \\
\hline $\mathrm{TiO}_{2}$ & 0.11 & 0.09 & 0.11 & 0.07 & 0.06 & 0.00 & 0.03 & 37.76 \\
\hline $\mathrm{Al}_{2} \mathrm{O}_{3}$ & 22.33 & 24.55 & 25.86 & 25.73 & 18.38 & 19.95 & 0.03 & 1.66 \\
\hline $\mathrm{Cr}_{2} \mathrm{O}_{3}$ & 0.06 & 0.08 & 0.02 & 0.09 & 0.07 & 0.01 & 0.01 & 0.05 \\
\hline $\mathrm{Fe}_{2} \mathrm{O}_{3}$ & 3.38 & 0.00 & 0.00 & 9.58 & 0.00 & 0.14 & 0.00 & 0.00 \\
\hline $\mathrm{FeO}$ & 1.31 & 2.72 & 3.30 & 0.09 & 23.73 & 0.00 & 0.38 & 0.34 \\
\hline Mno & 0.07 & 0.13 & 0.00 & 0.12 & 0.41 & 0.00 & 0.00 & 0.09 \\
\hline MgO & 4.85 & 3.73 & 3.00 & 0.07 & 16.02 & 0.00 & 0.00 & 0.01 \\
\hline $\mathrm{CaO}$ & 0.02 & 0.01 & 0.01 & 22.76 & 0.04 & 0.02 & 51.98 & 28.00 \\
\hline $\mathrm{Na}_{2} \mathrm{O}$ & 0.03 & 0.09 & 0.13 & 0.00 & 0.00 & 11.89 & 0.00 & 0.01 \\
\hline $\mathrm{K}_{2} \mathrm{O}$ & 10.37 & 10.95 & 10.98 & 0.03 & 0.11 & 0.02 & 0.03 & 0.07 \\
\hline Total & 92.79 & 91.93 & 92.43 & 96.59 & 85.81 & 100.63 & 52.46 & 98.23 \\
\hline \multicolumn{9}{|c|}{ Data calculated with AX sofware (Holland and Powell, 1998) } \\
\hline $\mathrm{Si}$ & 3.48 & 3.46 & 3.41 & 3.02 & 2.89 & 2.98 & 0.00 & 1.00 \\
\hline $\mathrm{Ti}$ & 0.01 & 0.01 & 0.01 & 0.00 & 0.01 & 0.00 & 0.00 & 0.94 \\
\hline Al & 1.82 & 2.02 & 2.12 & 2.41 & 2.32 & 1.02 & 0.00 & 0.07 \\
\hline $\mathrm{Cr}$ & 0.00 & 0.00 & 0.00 & 0.01 & 0.01 & 0.00 & 0.00 & 0.00 \\
\hline $\mathrm{Fe}^{3+}$ & 0.18 & 0.00 & 0.00 & 0.57 & 0.00 & 0.00 & 0.00 & 0.00 \\
\hline $\mathrm{Fe}^{2+}$ & 0.08 & 0.16 & 0.19 & 0.01 & 2.12 & 0.00 & 0.01 & 0.01 \\
\hline $\mathrm{Mn}$ & 0.00 & 0.01 & 0.00 & 0.01 & 0.04 & 0.00 & 0.00 & 0.00 \\
\hline $\mathrm{Mg}$ & 0.50 & 0.39 & 0.31 & 0.01 & 2.56 & 0.00 & 0.00 & 0.00 \\
\hline $\mathrm{Ca}$ & 0.00 & 0.00 & 0.00 & 1.94 & 0.01 & 0.00 & 1.99 & 1.00 \\
\hline $\mathrm{Na}$ & 0.00 & 0.01 & 0.02 & 0.00 & 0.00 & 1.00 & 0.00 & 0.00 \\
\hline K & 0.92 & 0.97 & 0.97 & 0.00 & 0.02 & 0.00 & 0.00 & 0.00 \\
\hline $\mathrm{X}_{\mathrm{Mg}}$ & & & 0.62 & & 0.55 & & & 0.04 \\
\hline $\mathrm{X}_{\mathrm{Na}}$ & 0.00 & 0.01 & 0.02 & & & & & \\
\hline $\mathrm{X}_{\mathrm{Fe}}$ & 0.13 & 0.29 & 0.38 & 0.19 & & & & \\
\hline An & & & & & & 0.10 & & \\
\hline $\mathrm{Ab}$ & & & & & & 99.80 & & \\
\hline Or & & & & & & 0.10 & & \\
\hline
\end{tabular}

porphyroblasts and is associated with relatively low Si phengitic white mica ( $\mathrm{Si}=3.2$ a.p.f.u.) (Fig. 7.4). Within the metapelites, in sample 110.430 chlorites show less $\mathrm{X}_{\mathrm{Mg}}(0.43 \mathrm{apfu})$ than the chlorites in sample $110.434\left(\mathrm{X}_{\mathrm{Mg}}=0.55\right)$. In the mafic schists, the chlorites are notably more magnesian $\left(\mathrm{X}_{\mathrm{Mg}}=0.67-0.72\right)$ than in the pelitic schist (Tables 1-4). This slight increase in the $X_{M g}$ content is related with the mafic composition.

\subsection{Plagioclase}

Plagioclase is almost exclusively albite in all the samples. The mineral occurs as millimeter-sized porphyroblasts and as late-stage veins and is found closely intergrown with chlorite. In LBS, the albite and orthoclase content varies from 81 to 96 wt.\% and 3.5 to $19 \mathrm{wt} . \%$, respectively. Plagioclases in the EBS are nearly pure albite, reaching a maximum of $99.9 \mathrm{wt} \%$ in albite content (Tables 1-4).

\subsubsection{Titanite and magnetite}

Titanite appears as allotriomorphic matrix grains $(\approx 20 \mu \mathrm{m}$ long $)$ in LBS and EPS. In the EBS metabasites, it occurs as disordered aggregates in calcite veins $(\approx 15-30 \mu \mathrm{m}$ long) and partially replacing epidote crystal rims and fractures. The titanites do not show chemical zoning and are characterized by low $\mathrm{Al}_{2} \mathrm{O}_{3}$ contents, reaching a maximum of $2.17 \mathrm{wt} \%$ in the LBS. The accessory magnetite inclusions are small, averaging 1$3 \mu \mathrm{m}$ or less in diameter. Magnetite forms micro inclusions in epidote grains in EBS metabasites (see Fig. 7B).

\subsubsection{Carbonates and apatite}

The X-ray diffraction analyses carried out in this study have provided the identification of the high-pressure carbonate phase aragonite, typically associated with well-preserved low temperature blueschist parageneses. The aragonite grains are only in the LBS, whereas in the EBS the carbonates are calcite crystals and veins. Apatite is present only in the LBS, where it constitutes the most abundant accessory mineral. The sub-idiomorphic crystals do not exceed $25 \mu \mathrm{m}$ in length. $\mathrm{Fl}$ and $\mathrm{Cl}$ have not been detected in the grains.

\subsection{Phase equilibria modeling}

Pressure-temperature $(P-T)$ pseudosections were calculated with the PERPLE_X computer program package (Connolly, 1990; 2005, updated July, 2010) for the P-T range of 5-20 kbar and $200-600{ }^{\circ} \mathrm{C}$ using the thermodynamic data set of Holland and Powell (1998, updated 2004) for mineral end members. The following solid solution models for pseudosection calculation were chosen from the most updated solution file (solution_model.dat): $\mathrm{Mica}(\mathrm{CHA})$ for white mica (Auzanneau et al., 2010; Coggon and Holland, 2002), Chl(HP), Ctd (HP) and $\mathrm{Ep}(\mathrm{HP})$ for chlorite, chloritoid and epidote, respectively (Holland and Powell, 1998), cAmph(DP) for amphibole (Diener et al., 2007), Omph(GHP) for clinopyroxene (Green et al., 2007), Gt(WHP) for garnet (White et al., 2000), $\operatorname{IlHm}(\mathrm{A})$ and $\mathrm{MtUl}(\mathrm{A})$ for ilmenite and magnetite (Andersen and Lindsley, 1988), Bio(TCC) for biotite (Tajcmanová et al., 2009), and $\mathrm{Ab}(\mathrm{h})$ for plagioclase (Newton et al., 1980). The fluid phase was fixed as pure $\mathrm{H}_{2} \mathrm{O}$ in excess based on the tectonic setting of these rocks within a hydrous subduction regime. $\mathrm{CO}_{2}$ has been excluded from the calculations and $\mathrm{SiO}_{2}$ is considered to be in excess.

Bulk compositions were determined by whole rock analyses of the same five samples used for petrographic studies using X-ray Fluorescence Spectroscopy (XRF). A representative slab of each sample was chosen: one LBS (sample 110.430) and four EBS (samples 110.431-434). The $P-T$ pseudosections were computed for the system $\mathrm{Na}_{2} \mathrm{O}-\mathrm{CaO}-\mathrm{K}_{2} \mathrm{O}-\mathrm{FeO}-\mathrm{MgO}-\mathrm{Al}_{2} \mathrm{O}_{3}-\mathrm{SiO}_{2}-\mathrm{TiO}_{2}-\mathrm{Fe}_{2} \mathrm{O}_{3}$ (NCKFMASHTO). The original compositions of the studied rocks were simplified to fit this system (Table 5).

The final pseudosections (Figs. 11 and 12) were redrawn as demonstrated by Connolly (2005). The compositional isopleths for Si and $\mathrm{Fe}$ content in phengite were generated using werami program from Perple_X package and plotted with pscontor and Python programs. Werami program has been used also to get the composition of each phase at particular $P-T$ conditions.

Estimating the $P-T$ conditions of the schists from Liberty Creek by conventional methods is problematic since no suitable geothermobarometer can be applied to these rocks. Moreover, the strong reequilibration into greenschist and epidote-amphibolite facies assemblages displayed by all samples, and their small grain size, compounds this problem. In this work, we therefore addressed this issue by calculating the $P-T$ conditions by pseudosections. However it is important to make some preliminary considerations based on the mineral assemblages. The absence of garnet in all the samples indicates a low temperature setting for the initial high-pressure event ( $c a$. $\geq 400^{\circ} \mathrm{C}$ ). The presence of lawsonite in sample 110.430 is also a key indicator of the high pressure nature of these rocks. This hydrous mineral is stable over a wide $P$ - $T$ range in the low- $T$ blueschist facies, but rarely preserved.

We computed P-T pseudosections for four representative samples from the Liberty Creek schists: two pelitic schists (LBS; sample 110.430, EPB; sample 110.434) and two mafic schists (EBS; samples 110.431110.432 ). The results are shown in Figs. 11 and 12 were thick continuous and dashed lines indicate the stability field of diagnostic phases and thick black lines represents the proposed $\mathrm{P}-\mathrm{T}$ path. $\mathrm{Jd}+\mathrm{Qtz} \rightarrow \mathrm{Ab}$ reaction (Holland, 1980) is shown as reference. White fields are divariant and increasing variance is shown with progressively darker shades of grey. Mineral abbreviations are after Kretz (1983), Holland and Powell (1998) and Whitney and Evans (2010). 
Table 3

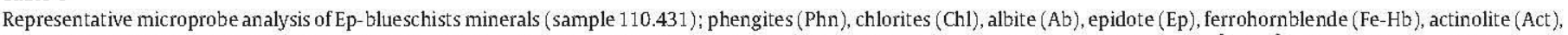

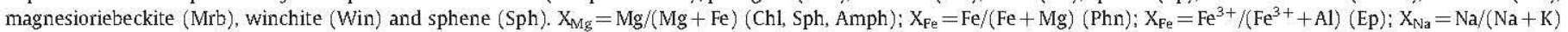
$(\mathrm{Phn}) ; \mathrm{X}_{\mathrm{Al}}=\mathrm{Al} /\left(\mathrm{Al}+\mathrm{Fe}^{3+}\right)(\mathrm{Amph}), \mathrm{An}=[\mathrm{Ca} /(\mathrm{Ca}+\mathrm{Na}+\mathrm{K})] 100, \mathrm{Ab}=[\mathrm{Na} /(\mathrm{Ca}+\mathrm{Na}+\mathrm{K})] 100, \mathrm{Or}=[\mathrm{K} /(\mathrm{Ca}+\mathrm{Na}+\mathrm{K})] 100$

\begin{tabular}{|c|c|c|c|c|c|c|c|c|c|c|c|c|c|}
\hline \multirow{2}{*}{$\frac{\text { Sample }}{\text { Mineral }}$} & \multicolumn{13}{|c|}{110,431} \\
\hline & \multirow{2}{*}{$\frac{\text { Phn }}{50}$} & \multirow{2}{*}{$\frac{\mathrm{Phn}}{54}$} & \multirow{2}{*}{$\frac{\mathrm{Chl}}{40}$} & \multirow{2}{*}{$\frac{\text { Ch1 }}{57}$} & \multirow{2}{*}{$\frac{\mathrm{Ab}}{58}$} & \multirow{2}{*}{$\frac{E p}{131}$} & \multirow{2}{*}{$\frac{\mathrm{Fe}-\mathrm{Hb}}{127}$} & \multirow{2}{*}{$\frac{\text { Act }}{130}$} & \multirow{2}{*}{$\frac{\text { Mrb }}{36}$} & \multirow{2}{*}{$\frac{\mathrm{Mrb}}{37}$} & \multirow{2}{*}{$\frac{\text { Win }}{35}$} & \multirow{2}{*}{$\frac{\text { Win }}{39}$} & \multirow{2}{*}{$\frac{\mathrm{Sph}}{44}$} \\
\hline Analysis & & & & & & & & & & & & & \\
\hline $\mathrm{SiO}_{2}$ & 55.02 & 55.51 & 27.77 & 28.36 & 68.99 & 37.71 & 42.51 & 54.64 & 53.05 & 54.54 & 53.80 & 55.46 & 30.60 \\
\hline $\mathrm{TiO}_{2}$ & 0.06 & 0.03 & 0.00 & 0.04 & 0.00 & 0.07 & 0.08 & 0.03 & 0.07 & 0.05 & 0.17 & 0.07 & 36.19 \\
\hline $\mathrm{Al}_{2} \mathrm{O}_{3}$ & 23.09 & 24.20 & 17.97 & 19.02 & 19.68 & 21.91 & 19.69 & 1.54 & 3.99 & 3.55 & 3.64 & 1.83 & 1.74 \\
\hline $\mathrm{Cr}_{2} \mathrm{O} 3$ & 0.00 & 0.03 & 0.06 & 0.04 & 0.00 & 0.02 & 0.04 & 0.03 & 0.03 & 0.03 & 0.07 & 0.05 & 0.06 \\
\hline $\mathrm{Fe}_{2} \mathrm{O}_{3}$ & 3.67 & 3.39 & 4.69 & 0.00 & 0.47 & 14.85 & 14.28 & 1.79 & 6.36 & 7.24 & 3.01 & 6.50 & 0.00 \\
\hline $\mathrm{FeO}$ & 1.42 & 1.31 & 16.88 & 19.60 & 0.00 & 0.13 & 0.00 & 11.28 & 13.14 & 12.38 & 13.81 & 8.36 & 1.15 \\
\hline $\mathrm{MnO}$ & 0.00 & 0.06 & 0.06 & 0.04 & 0.00 & 0.08 & 0.10 & 0.25 & 0.03 & 0.00 & 0.12 & 0.04 & 0.00 \\
\hline $\mathrm{MgO}$ & 4.65 & 4.67 & 19.66 & 19.00 & 0.00 & 0.00 & 0.73 & 15.14 & 9.65 & 9.57 & 11.08 & 13.31 & 0.07 \\
\hline $\mathrm{CaO}$ & 0.43 & 0.04 & 0.03 & 0.02 & 0.01 & 22.30 & 19.80 & 9.18 & 1.82 & 2.53 & 4.60 & 5.61 & 28.00 \\
\hline $\mathrm{Na}_{2} \mathrm{O}$ & 0.06 & 0.09 & 0.00 & 0.00 & 12.17 & 0.09 & 0.02 & 1.84 & 6.47 & 6.20 & 5.06 & 3.17 & 0.05 \\
\hline $\mathrm{K}_{2} \mathrm{O}$ & 8.37 & 8.95 & 0.01 & 0.00 & 0.01 & 0.01 & 0.00 & 0.05 & 0.00 & 0.03 & 0.04 & 0.01 & 0.05 \\
\hline Total & 96.77 & 98.28 & 87.13 & 86.12 & 101.33 & 97.17 & 97.25 & 95.77 & 94.61 & 96.12 & 95.40 & 94.41 & 97.91 \\
\hline \multicolumn{14}{|c|}{ Data calculated with AX software (Holland and Powell, 1998) } \\
\hline $\mathrm{Si}$ & 3.58 & 3.56 & 2.45 & 2.94 & 2.98 & 3.04 & 6.17 & 7.96 & 7.92 & 7.99 & 7.94 & 8.09 & 1.02 \\
\hline $\mathrm{Ti}$ & 0.00 & 0.00 & 0.00 & 0.00 & 0.00 & 0.00 & 0.01 & 0.00 & 0.01 & 0.01 & 0.02 & 0.01 & 0.91 \\
\hline Al & 1.77 & 1.83 & 3.44 & 2.32 & 1.00 & 2.08 & 3.37 & 0.26 & 0.70 & 0.61 & 0.63 & 0.32 & 0.07 \\
\hline $\mathrm{Cr}$ & 0.00 & 0.00 & 0.01 & 0.00 & 0.00 & 0.00 & 0.01 & 0.00 & 0.00 & 0.00 & 0.01 & 0.01 & 0.00 \\
\hline $\mathrm{Fe}^{3+}$ & 0.18 & 0.16 & 0.57 & 0.00 & 0.02 & 0.90 & 1.56 & 0.20 & 0.72 & 0.80 & 0.33 & 0.71 & 0.00 \\
\hline $\mathrm{Fe}^{2+}$ & 0.08 & 0.07 & 2.29 & 1.70 & 0.00 & 0.01 & 0.00 & 1.37 & 1.64 & 1.52 & 1.71 & 1.02 & 0.03 \\
\hline $\mathrm{Mn}$ & 0.00 & 0.00 & 0.01 & 0.00 & 0.00 & 0.01 & 0.01 & 0.03 & 0.00 & 0.00 & 0.02 & 0.01 & 0.00 \\
\hline $\mathrm{Mg}$ & 0.45 & 0.45 & 4.76 & 2.93 & 0.00 & 0.00 & 0.16 & 3.29 & 2.15 & 2.09 & 2.44 & 2.90 & 0.00 \\
\hline $\mathrm{Ca}$ & 0.03 & 0.00 & 0.01 & 0.00 & 0.00 & 1.93 & 3.08 & 1.43 & 0.29 & 0.40 & 0.73 & 0.88 & 1.00 \\
\hline $\mathrm{Na}$ & 0.01 & 0.01 & 0.00 & 0.00 & 1.02 & 0.02 & 0.01 & 0.52 & 1.87 & 1.76 & 1.45 & 0.90 & 0.00 \\
\hline K & 0.69 & 0.73 & 0.00 & 0.00 & 0.00 & 0.00 & 0.00 & 0.01 & 0.00 & 0.01 & 0.01 & 0.00 & 0.00 \\
\hline $\mathrm{X}_{\mathrm{Mg}}$ & & & 0.67 & 0.63 & & & 1.00 & 0.71 & 0.57 & 0.58 & 0.59 & 0.74 & 0.10 \\
\hline $\mathrm{X}_{\mathrm{Na}}$ & 0.01 & 0.01 & & & & & & 0.27 & 0.87 & 0.82 & 0.67 & 0.51 & \\
\hline $\mathrm{X}_{\mathrm{Fe}}$ & 0.15 & 0.14 & & & & 0.30 & 0.32 & 0.43 & 0.50 & 0.57 & 0.35 & 0.69 & \\
\hline $\mathrm{X}_{\mathrm{AI}}$ & & & & & & 0.70 & 0.68 & 0.57 & 0.50 & 0.43 & 0.65 & 0.31 & \\
\hline An & & & & & 0.00 & & & & & & & & \\
\hline $\mathrm{Ab}$ & & & & & 99.90 & & & & & & & & \\
\hline Or & & & & & 0.10 & & & & & & & & \\
\hline
\end{tabular}

\subsection{P-T paths and discussion}

The $P-T$ pseudosection for the LBS is shown in Fig. 11A. The coexistence of lawsonite and high silica phengite ( 3.56 c.p.f.u) marks a high-P limit around $19 \mathrm{kbar}$, constraining a maximum pressure for the LBS and confirming the high-P nature of this paragenesis. However, no chloritoid or carpholite are present. The intersection between the Si (3.56 c.p.f.u.) and the $\mathrm{Fe}(0.33-0.36$ c.p.f.u) isopleths in phengites provides another approximation for the maximum pressures reached, at 15-16 kbars. At these pressures magnesiocarpholite is still predicted as a stable phase in the paragenesis. However it has not been observed in the natural assemblage. Currently there is no a solid solution model for carpholite, being always considered for the petrologic modeling as pure (ideal solid solution). The stability of this phase is restricted to a narrow temperature window $\left(300-400^{\circ} \mathrm{C}\right.$ ) at elevated pressures (Mottana and Schreyer, 1977) so it may appear in the considered P-T range. The predicted presence of this mineral in the pseudeosection for the LBS can be explained by the limitations resulting from the absence of a proper solid solution model for this phase, which would affect to the actual extension of its stability field, or more probably to its consumption during retrograde reactions. The absence of the other phases predicted in the pseudosection and now not present in the LBS are equally interpreted as a result of retrograde metamorphism. For example, jadeite probably have been consumed during retrograde metamorphism to form albite according to the reaction $\mathrm{Jd}+\mathrm{Qtz}=$ $\mathrm{Ab}$ (Holland, 1980). No paragonite was found in these rocks. The boundary reaction between paragonite and albite is $\mathrm{Gln}+\mathrm{Zo}+\mathrm{Pg}+$ $\mathrm{H}_{2} \mathrm{O}=\mathrm{Chl}+\mathrm{Law}+\mathrm{Ab}$ (e.g. Heinrich and Althaus, 1988). Therefore, the possible interpretations are that paragonite was never present or it was consumed completely to form albite. The last hypothesis will also explain the absence of sodic amphibole in these rocks. However, the diagram predicts the presence of amphibole as a stable phase. According to the stability of lawsonite + phengite and the intersection of isopleths for Si and Fe content in white mica, the P-T conditions can be estimated as $220-280^{\circ} \mathrm{C}$ and $14-15 \mathrm{kbar}$. Garnet-free LBS with similar $P-T$ conditions and mineralogy have been reported in other high-pressure terranes (see i.e. L. Zhang et al., 2009; Z. Zhang et al., 2009).

In the pelitic EBS rocks (Fig. 11B), epidote is present in the matrix assemblage. The Si (3.46-3.48 c.p.f.u) and the Fe (0.13-0.29 c.p.f.u) content in phengites suggests approximate $P-T$ conditions of $18 \mathrm{kbar}$ and $400^{\circ} \mathrm{C}$. However, no lawsonite has been found in these rocks. Clinozoisite could be a product of retrograde metamorphism replacing earlier lawsonite. Based on the presence of clinozoisite in the natural paragenesis the $P-T$ path could evolve to the 4-variant field chl-ph-pgczo-jd-ru. But paragonite, jadeite and rutile are absent in these rocks. The presence of albite and sphene and the lack of biotite suggests a rapid decompression at $10 \mathrm{kbar}$ with a slightly decrease in temperature from 450 to $400{ }^{\circ} \mathrm{C}$. Again; the presence of amphiboles, clinopyroxene and paragonite in the intermediate fields does not conform to the petrographic observations. The mode of rutile in all the assemblages is very low (up to a maximum of $0.15 \%$ ). The lack of this phase could be explained due to its fine-grained size precluding detection by routine microprobe techniques. In the case of clinopyroxenes and paragonite the same reactions explained previously could take place, justifying the absence of these phases. Regarding omphacite alternate possibilities are that the mineral could have been totally consumed to form carbonates, or that it was never present.

The mafic EBS pseudosections are shown in Fig. 12A and B. Lawsonite is the only high-P phase predicted that has not been observed either as inclusions or in the matrix. However, this mineral has been 
Table 4

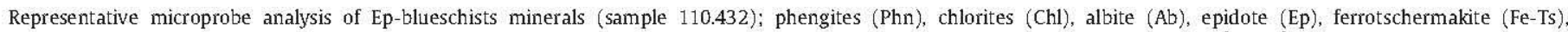

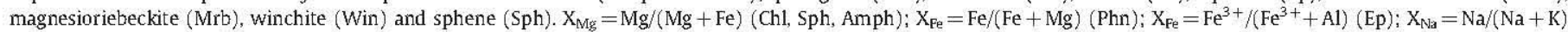
$(\mathrm{Phn}) ; \mathrm{X}_{\mathrm{Al}}=\mathrm{Al} /\left(\mathrm{Al}+\mathrm{Fe}^{3+}\right)(\mathrm{Amph}), \mathrm{An}=[\mathrm{Ca} /(\mathrm{Ca}+\mathrm{Na}+\mathrm{K})] 100, \mathrm{Ab}=[\mathrm{Na} /(\mathrm{Ca}+\mathrm{Na}+\mathrm{K})] 100, \mathrm{Or}=[\mathrm{K} /(\mathrm{Ca}+\mathrm{Na}+\mathrm{K})] 100$.

\begin{tabular}{|c|c|c|c|c|c|c|c|c|c|c|c|c|}
\hline \multirow{2}{*}{$\frac{\text { Sample }}{\text { Mineral }}$} & \multicolumn{12}{|c|}{110,432} \\
\hline & \multirow{2}{*}{$\frac{\mathrm{Phn}}{72}$} & \multirow{2}{*}{$\frac{\mathrm{Phn}}{111}$} & \multirow{2}{*}{$\frac{\mathrm{Chl}}{66}$} & \multirow{2}{*}{$\frac{\mathrm{Chl}}{88}$} & & \multirow{2}{*}{$\frac{E p}{22}$} & \multirow{2}{*}{$\frac{\mathrm{Fe}-\mathrm{Ts}}{84}$} & \multirow{2}{*}{$\frac{\text { Mrb }}{106}$} & \multirow{2}{*}{$\frac{\mathrm{Mrb}}{110}$} & \multirow{2}{*}{$\frac{\text { Win }}{77}$} & \multirow{2}{*}{$\frac{\text { Win }}{78}$} & \multirow{2}{*}{$\frac{\mathrm{Sph}}{25}$} \\
\hline Analysis & & & & & & & & & & & & \\
\hline $\mathrm{SiO}_{2}$ & 45.53 & 45.83 & 30.05 & 28.86 & 68.23 & 37.13 & 40.29 & 55.25 & 55.15 & 52.67 & 53.23 & 30.53 \\
\hline $\mathrm{TiO}_{2}$ & 0.09 & 0.07 & 0.00 & 0.00 & 0.04 & 0.00 & 0.04 & 0.08 & 0.03 & 0.02 & 0.28 & 38.27 \\
\hline $\mathrm{Al}_{2} \mathrm{O}_{3}$ & 21.30 & 20.98 & 18.11 & 17.37 & 19.49 & 21.43 & 19.74 & 3.17 & 3.13 & 5.31 & 4.37 & 0.91 \\
\hline $\mathrm{Cr}_{2} \mathrm{O}_{3}$ & 0.14 & 0.08 & 0.07 & 0.05 & 0.02 & 0.07 & 0.02 & 0.07 & 0.08 & 0.06 & 0.08 & 0.04 \\
\hline $\mathrm{Fe}_{2} \mathrm{O}_{3}$ & 5.97 & 5.52 & 0.00 & 0.00 & 0.16 & 15.10 & 14.14 & 8.70 & 8.38 & 6.87 & 5.54 & 0.00 \\
\hline $\mathrm{FeO}$ & 2.30 & 2.13 & 15.51 & 15.99 & 0.00 & 0.14 & 0.00 & 7.31 & 8.05 & 10.16 & 9.40 & 0.77 \\
\hline $\mathrm{MnO}$ & 0.11 & 0.10 & 0.36 & 0.48 & 0.02 & 0.00 & 0.20 & 0.17 & 0.13 & 0.19 & 0.11 & 0.00 \\
\hline $\mathrm{MgO}$ & 9.64 & 8.44 & 21.53 & 22.61 & 0.01 & 0.02 & 4.64 & 12.32 & 12.16 & 12.42 & 12.82 & 0.05 \\
\hline $\mathrm{CaO}$ & 0.01 & 0.05 & 0.04 & 0.01 & 0.02 & 22.00 & 16.30 & 2.85 & 2.79 & 1.49 & 2.91 & 27.60 \\
\hline $\mathrm{Na}_{2} \mathrm{O}$ & 0.03 & 0.02 & 0.01 & 0.00 & 11.99 & 0.03 & 0.03 & 5.63 & 5.81 & 5.86 & 5.33 & 0.02 \\
\hline $\mathrm{K}_{2} \mathrm{O}$ & 8.23 & 8.45 & 0.57 & 0.00 & 0.02 & 0.00 & 0.00 & 0.02 & 0.07 & 0.07 & 0.01 & 0.07 \\
\hline Total & 93.35 & 91.67 & 86.25 & 85.37 & 100.00 & 95.92 & 95.40 & 95.57 & 95.78 & 95.12 & 94.08 & 98.26 \\
\hline \multicolumn{13}{|c|}{ Data calculated with AX software (Holland and Powell, 1998) } \\
\hline $\mathrm{Si}$ & 3.18 & 3.25 & 3.05 & 2.97 & 2.99 & 3.03 & 5.94 & 7.98 & 7.97 & 7.71 & 7.83 & 1.01 \\
\hline $\mathrm{Ti}$ & 0.01 & 0.00 & 0.00 & 0.00 & 0.00 & 0.00 & 0.00 & 0.01 & 0.00 & 0.00 & 0.03 & 0.96 \\
\hline $\mathrm{Al}$ & 1.75 & 1.75 & 2.17 & 2.11 & 1.01 & 2.06 & 3.43 & 0.54 & 0.53 & 0.92 & 0.76 & 0.04 \\
\hline $\mathrm{Cr}$ & 0.01 & 0.00 & 0.01 & 0.00 & 0.00 & 0.00 & 0.00 & 0.01 & 0.01 & 0.01 & 0.01 & 0.00 \\
\hline $\mathrm{Fe}^{3+}$ & 0.31 & 0.30 & 0.00 & 0.00 & 0.01 & 0.93 & 1.57 & 0.95 & 0.91 & 0.76 & 0.61 & 0.00 \\
\hline $\mathrm{Fe}^{2+}$ & 0.13 & 0.13 & 1.32 & 1.38 & 0.00 & 0.01 & 0.00 & 0.88 & 0.97 & 1.24 & 1.16 & 0.02 \\
\hline $\mathrm{Mn}$ & 0.01 & 0.01 & 0.03 & 0.04 & 0.00 & 0.00 & 0.03 & 0.02 & 0.02 & 0.02 & 0.01 & 0.00 \\
\hline $\mathrm{Mg}$ & 1.00 & 0.89 & 3.26 & 3.47 & 0.00 & 0.00 & 1.02 & 2.65 & 2.62 & 2.71 & 2.81 & 0.00 \\
\hline $\mathrm{Ca}$ & 0.00 & 0.00 & 0.00 & 0.00 & 0.00 & 1.93 & 2.57 & 0.44 & 0.43 & 0.23 & 0.46 & 0.98 \\
\hline $\mathrm{Na}$ & 0.00 & 0.00 & 0.00 & 0.00 & 1.02 & 0.00 & 0.01 & 1.58 & 1.63 & 1.66 & 1.52 & 0.00 \\
\hline K & 0.73 & 0.77 & 0.07 & 0.00 & 0.00 & 0.00 & 0.00 & 0.00 & 0.01 & 0.01 & 0.00 & 0.00 \\
\hline $\mathrm{X}_{\mathrm{Mg}}$ & 0.88 & 0.88 & 0.71 & 0.72 & & & 1.00 & 0.75 & 0.73 & 0.69 & 0.71 & \\
\hline $\mathrm{X}_{\mathrm{Na}}$ & 0.01 & 0.00 & & & & & 0.00 & 0.78 & 0.79 & 0.88 & 0.77 & \\
\hline $\mathrm{X}_{\mathrm{Fe}}$ & 0.12 & 0.12 & & & & 0.31 & 0.31 & 0.64 & 0.63 & 0.45 & 0.45 & \\
\hline $\mathrm{X}_{\mathrm{Al}}$ & & & & & & 0.69 & 0.69 & 0.36 & 0.37 & 0.55 & 0.55 & \\
\hline An & & & & & 0.10 & & & & & & & \\
\hline $\mathrm{Ab}$ & & & & & 99.80 & & & & & & & \\
\hline Or & & & & & 0.10 & & & & & & & \\
\hline
\end{tabular}

found in the associated pelitic schists from Liberty Creek. Also we consider the possibility that some of the abundant crystals of zoisite/ clinozoisite found in the matrix of the mafic schists could have been formed at the expense of earlier lawsonite in the rock. The growth of late albite porphyroblasts in some levels indicates a dramatic decompression from the fields with lawsonite to the fields with stable albite. Further constraints can be placed from the fact that the samples contain Na-amphibole and phengite, indicating that the $P-T$ path should first pass through the fields with this assemblage and then through those with albite. In sample 110.431 the fields that best fits the petrographic data comprises the shaded area between $5-9$ kbar and $250-350{ }^{\circ} \mathrm{C}$ (Figs. 12A and 13). The intersection between the Si (3.58 c.p.f.u) and the Fe $(0.15$ c.p.f.u) isopleths in phengites support this data. However, the mode of lawsonite and pyroxene in these parageneses is extremely high compared with that of epidote, besides the absence of calcic amphiboles. Therefore, in this case the intersection of the silica isopleths cannot be considered as a reliable barometer (see i.e. Massone and Schreyer, 1987). Based on the highest silica content analyzed in phengites ( 3.58 c.p.f.u) the P-T path that best fits with the petrographic observations would start in the 4-variance field jd-chl-ph-law-ilm-ru evolving through jd-chl-ph-law-ep-ru, reporting the first occurrence of epidote coexisting with lawsonite, crossing the field omp-chl-ph-ep-ru, to enter in the 3-variance field omp-chl-ep-ph-pg-sph-ru (with the formation of paragonite and sphene and the consumption of ilmenite), going finally to omp-chl-ep-ph-sph-ab, from the EBS fiels to the GS field. The resulting $P-T$ path suggests strong isothermal decompression from ca. $17 \mathrm{kbar}$ to $7 \mathrm{kbar}$, with a temperature peak around $425^{\circ} \mathrm{C}$. The mode of each phase in the parageneses bear out this trajectory, and the presence of biotite limit the temperature to a maximum value of $450{ }^{\circ} \mathrm{C}$ However the absence of amphiboles in all the area does not conform to the natural assemblages. In sample 110.432 the presence of epidote and the silica isopleths in phengite (3.25 c.p.f.u) points to maximum pressure conditions at about $18 \mathrm{kbar}$ and $450^{\circ} \mathrm{C}$ in the 4-variance field omp-chl-ep-ph-pg-ru. The $P-T$ path could have reached higher pressures starting in the EBS field, but no petrographic evidence of this fact can support this hypothesis. The evidence of sodic and sodiccalcic amphiboles suggests that the $P-T$ path evolves to a temperature of $500{ }^{\circ} \mathrm{C}$ crossing the fields omp-Namp-ep-ph-pg-ru and omp-NCampep-ph-ab-ru, where albite appears and paragonite disappears. Finally from $500{ }^{\circ} \mathrm{C}$ to $400{ }^{\circ} \mathrm{C}$ the path crosses the 4-variance field omp-NCampep-ph-sph-ab in the epidote-amphibolite facies to end in the ompCamp-chl-ep-ph-sph-ab field, with the appearance of calcic amphibole, as corroborated by petrographic data.

A synthesis of the results is shown in Fig. 13 where thick black line represents the calculated $P-T$ paths.

\section{Petrologic modeling conclusions}

Comparing the pseudosection calculations with the petrographic observations some important considerations can be concluded. Currently analytical techniques cannot identify how many $\mathrm{Fe}_{2} \mathrm{O}_{3}$ and $\mathrm{FeO}$ of the $\mathrm{FeO}_{\mathrm{T}}$ comes from re-equilibration or is primary. These uncertainties are directly connected with the results when using particular solid solution models (i.e. amphiboles, epidote group minerals or Ti and $\mathrm{Fe}^{2+} / \mathrm{Fe}^{3+}$ rich-oxides) as they are extremely sensitive in terms of the proportion of certain elements. However, although the strong re-equilibration into greenschist and epidote-amphibolite facies assemblages displayed by all samples influences the final mineralogy, the $P-T$ diagrams are not affected and show the whole metamorphic evolution. 
A

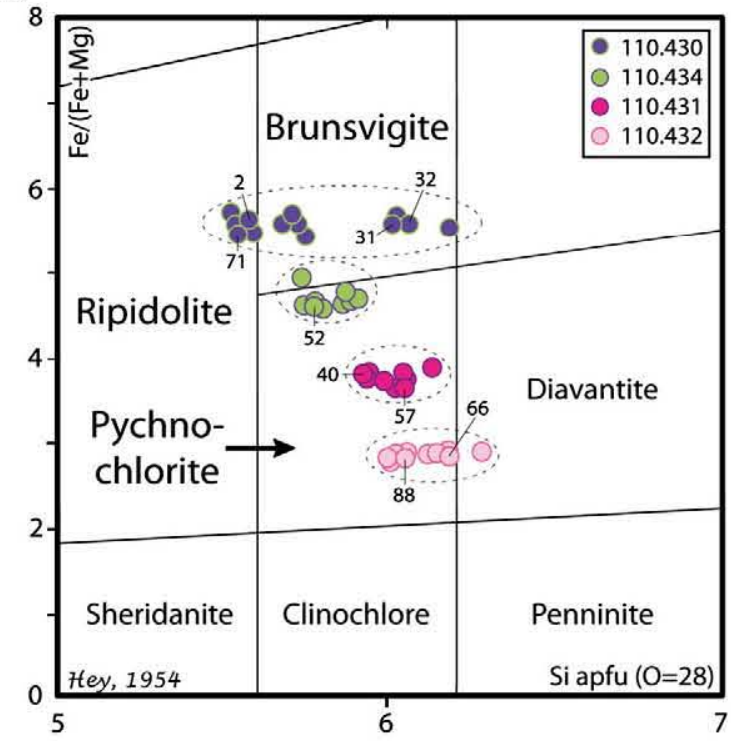

B

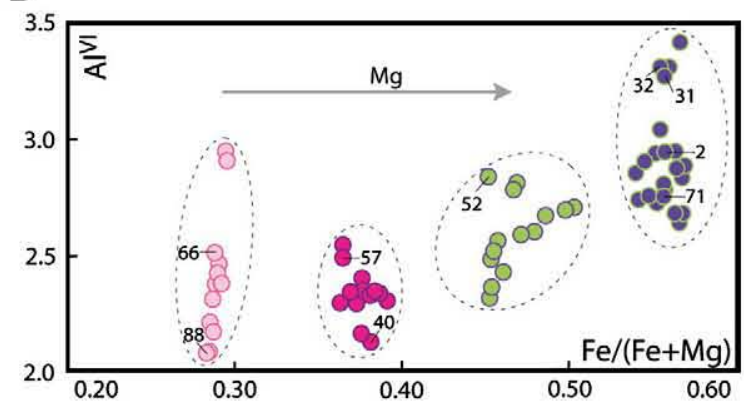

Fig. 10. (A) Chemical composition of chlorites in the Liberty Creek Schists plotted in Hey's diagram (Hey, 1954). (B) Compositional variations of chlorite in terms of $[\mathrm{Fe} /(\mathrm{Fe}+\mathrm{Mg})]$ vs. $\mathrm{Al}^{\mathrm{v}}$. Pointed numbers correspond to EMP analysis listed in Tables 1-4.
Since calculations are performed in the NCKFMASHTO chemical frame, our model system considers two tricky components - $\mathrm{TiO}_{2}$ and $\mathrm{Fe}_{2} \mathrm{O}_{3}$ - because of 1 ) the incomplete knowledge of the thermodynamic properties of $\mathrm{Fe}^{3+}$-end members in the available solid solution models and 2) the remaining uncertainties on the effect of $\mathrm{TiO}_{2}$, mainly in amphiboles and pyroxenes, as its solid solution models do not contain this component. Thus, when involving $\mathrm{TiO}_{2}$ in the calculations it does not work for some bulk-rock compositions because: 2.1 ) the stability field of amphibole is suppressed or becomes irregular senseless shapes. 2.2) The stability field of pyroxenes shown in the diagrams is unrealistic in nature. 2.3) Considering $\mathrm{TiO}_{2}$ avoids reducing the $\mathrm{CaO}$ bulk content which is involved in titanite but on the other hand, 2.4) the stability of Ti-rich phases such as rutile and ilmenite is overestimated.

The presence of lawsonite is crucial for the evaluation of the mechanisms of exhumation of these rocks (e.g. L. Zhang et al., 2009; Z. Zhang et al., 2009, with references therein). In the Liberty Creek Schists lawsonite has been found only in sample 110.430 and all observed epidote was present alone. As demonstrated by Davis and Whitney (2006) in all pseudosections when epidote and lawsonite coexists it is in a phase field rather than on a univariant line. The reaction glaucophane + lawsonite $=$ albite + clinozoisite + clinochlore + quartz $+\mathrm{H}_{2} \mathrm{O}$ can tightly constrain the metamorphic temperatures rather than the stability of lawsonite or epidote alone. This equilibrium is one of the many describing the transition from lawsonite blueschists to epidote blueschists (Evans, 1990) that can be followed in all diagrams. Therefore, we consider the possibility that some of the abundant crystals of epidote found in the matrix of samples 110.431-110.434 could have been formed at the expense of earlier lawsonite.

Finally, the growth of late albite porphyroblasts in all samples suggests a dramatic decompression, as also evidenced in the general trend of all paths in the calculated pseudosections.

\section{General Conclusions}

The Liberty Creek Schist outcrops over an area $28 \mathrm{~km}$ long and up to $13 \mathrm{~km}$ wide. The blueschist-bearing metamorphic rocks occur

Table 5

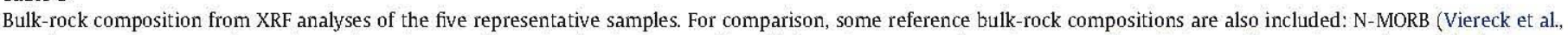

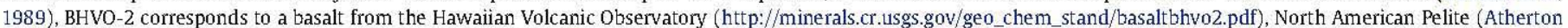

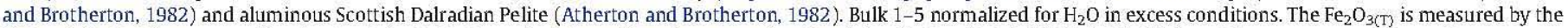
$\mathrm{XRF}$ and the $\mathrm{FeO}$ is measured by titration. The $\mathrm{Fe}_{2} \mathrm{O}_{3}$ is a calculation taking the converting: [total iron/1.43 - (FeO/1.286)*1.43]. All the oxides are expressed in wt.\%.

\begin{tabular}{|c|c|c|c|c|c|c|c|c|c|}
\hline & 110,430 & 110,431 & 110,432 & 110,433 & 110,434 & N-MORB & BHVO-2 & NAP & $\mathrm{Al}-\mathrm{SDP}$ \\
\hline & AL06ET-11 & AL06ET-13 & AL06ET-22B & AL06ET-22C & AL06ET-25 & \multicolumn{4}{|c|}{ model bulk compositions } \\
\hline $\mathrm{SiO}_{2}$ & 59.96 & 51.70 & 47.93 & 46.14 & 57.65 & $49.8-51.66$ & 49.90 & 61.54 & 59.88 \\
\hline $\mathrm{TiO}_{2}^{2}$ & 0.84 & 1.05 & 1.26 & 1.16 & 0.86 & $1.36-1.62$ & 2.73 & 0.82 & 1.03 \\
\hline $\mathrm{Al}_{2} \mathrm{O}_{3}$ & 16.20 & 12.88 & 14.09 & 16.49 & 15.94 & $14.32-16.28$ & 13.50 & 16.95 & 19.15 \\
\hline $\mathrm{FeO}$ & 6.25 & 8.87 & 4.56 & 4.46 & 5.48 & & & 3.90 & 5.15 \\
\hline $\mathrm{Fe}_{2} \mathrm{O}_{3}$ & 0.72 & 2.98 & 5.94 & 5.87 & 1.90 & & & 2.56 & 2.49 \\
\hline $\mathrm{FeO}_{\mathrm{T}}$ & 6.97 & 11.85 & 10.50 & 10.33 & 7.38 & $8.91-11.02$ & 12.30 & 6.46 & \\
\hline $\mathrm{MnO}$ & 0.10 & 0.17 & 0.18 & 0.17 & 0.14 & $0.16-0.20$ & & & 0.12 \\
\hline $\mathrm{MgO}$ & 3.10 & 8.67 & 6.29 & 4.32 & 3.54 & $6.09-8.06$ & 7.23 & $2.52 \pm 1.91$ & 2.34 \\
\hline $\mathrm{CaO}$ & 1.95 & 4.65 & 8.65 & 10.65 & 3.94 & $11.07-11.95$ & 11.40 & $1.76 \pm 2.03$ & 1.03 \\
\hline $\mathrm{Na}_{2} \mathrm{O}$ & 2.23 & 1.23 & 2.88 & 3.37 & 3.98 & $2.20-2.65$ & 2.22 & $1.84 \pm 1.18$ & 2.10 \\
\hline $\mathrm{K}_{2} \mathrm{O}$ & 2.56 & 1.26 & 1.17 & 1.40 & 1.01 & $0.08-0.52$ & 0.52 & $3.45 \pm 1.32$ & 3.50 \\
\hline $\mathrm{P}_{2} \mathrm{O}_{5}$ & 0.22 & 0.10 & 0.10 & 0.15 & 0.24 & $0.11-0.15$ & 0.27 & & \\
\hline $\mathrm{NiO}$ & 0.00 & 0.00 & 0.00 & 0.00 & 0.00 & & & & \\
\hline \multirow[t]{3}{*}{$\mathrm{Cr}_{2} \mathrm{O}_{3}$} & 0.03 & 0.05 & 0.05 & 0.07 & 0.02 & & & & \\
\hline & \multicolumn{9}{|c|}{ NCKFMASHTO $\left(\mathrm{H}_{2} \mathrm{O}\right.$ in excess $)$} \\
\hline & $\mathrm{Na}_{2} \mathrm{O}$ & $\mathrm{CaO}$ & $\mathrm{K}_{2} \mathrm{O}$ & $\mathrm{FeO}$ & MgO & $\mathrm{Al}_{2} \mathrm{O}_{3}$ & $\mathrm{SiO}_{2}$ & $\mathrm{TiO}_{2}$ & $\mathrm{Fe}_{2} \mathrm{O}_{3}$ \\
\hline 110,430 & 2.52 & 2.07 & 1.90 & 6.09 & 5.38 & 11.13 & 69.86 & 0.74 & 0.32 \\
\hline 110,431 & 1.35 & 5.48 & 0.91 & 8.39 & 14.62 & 8.59 & 58.50 & 0.89 & 1.27 \\
\hline 110,432 & 3.27 & 10.70 & 0.88 & 4.47 & 10.99 & 9.74 & 56.21 & 1.11 & 2.62 \\
\hline 110,433 & 3.87 & 13.26 & 1.06 & 4.42 & 7.62 & 11.51 & 54.62 & 1.03 & 2.61 \\
\hline 110,434 & 4.45 & 4.48 & 0.74 & 5.29 & 6.09 & 10.84 & 66.53 & 0.75 & 0.83 \\
\hline
\end{tabular}


A

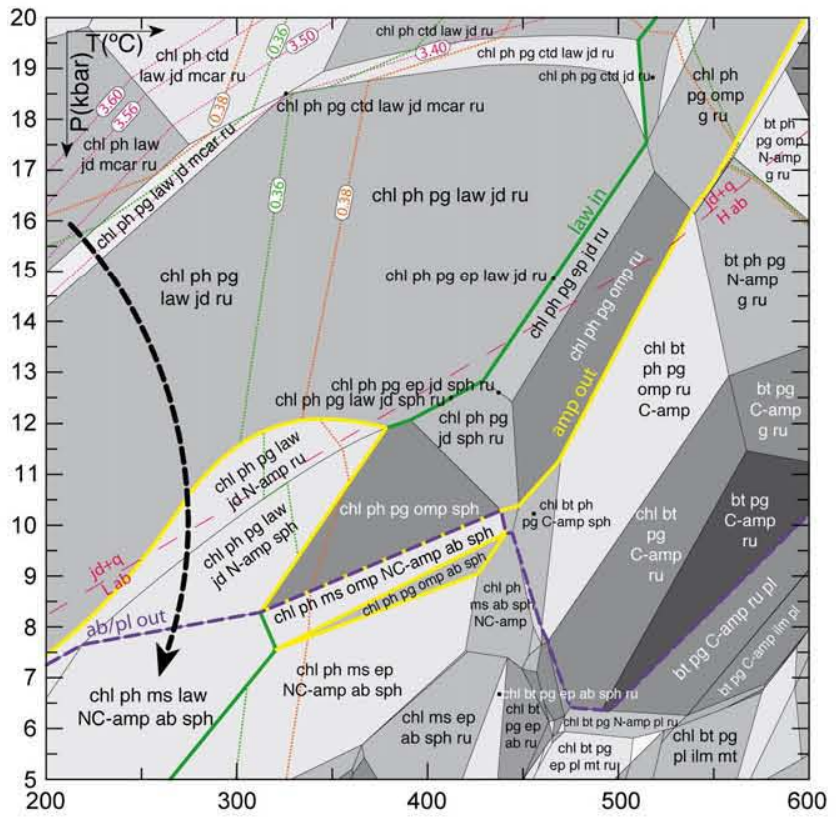

B

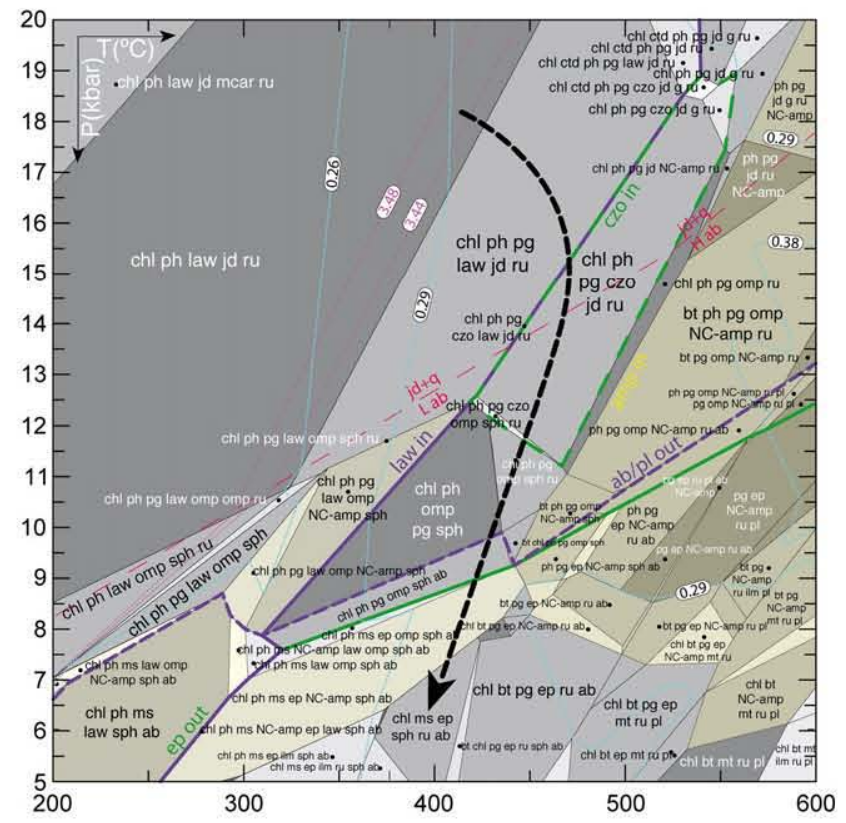

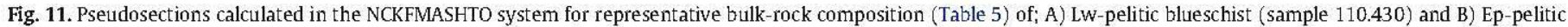
blueschist (sample 110.434). Thin dashed lines correspond to $\mathrm{Fe}^{2+}$ and $\mathrm{Si}$ isopleths in phengites (c.p.f.u.).

near the Border Ranges Fault in the eastern Valdez quadrangle of the northern Chugach Mountains. The rock types are mostly greenschist and blueschist, and also include muscovite and actinolite schist, siliceous schist, metachert, and graphitic schist. The protolith was mostly basaltic pillow flows, tuffs, tuff breccias, and volcaniclastic rocks with minor chert, carbonate, and argillaceous rocks; some faint primary structures at Liberty Creek suggest breccia or pillow breccia. At least two generations of folds exist in the Liberty Creek Schist-an earlier southverging set of folds overprinted by younger, north-verging folds and a later brittle-shearing event mid-Cretaceous or younger. The metamorphic minerals have been isotopically dated, giving Late Triassic to mid-
Cretaceous crystallization ages, which would have occurred during deep subduction (Plafker and Berg, 1994) reaching to $50-55 \mathrm{~km}$.

The Liberty Creek schist is correlative with the Seldovia blueschist belt on the Kenai Peninsula, as well as the Raspeberry Schist on Kodiak, Afognak and Shuyak islands.

The Seldovia, Liberty Creek, and Raspberry schists preserve typical subduction zone blueschist facies metamorphic assemblages in a complexly deformed volcanic-sedimentary sequence that has clear affinities with the McHugh Complex. The circa $190 \mathrm{Ma}$ (Early Jurassic) age of metamorphism likely records an early stage of subduction beneath Wrangellia, but there could be up to 40 million years between the
A

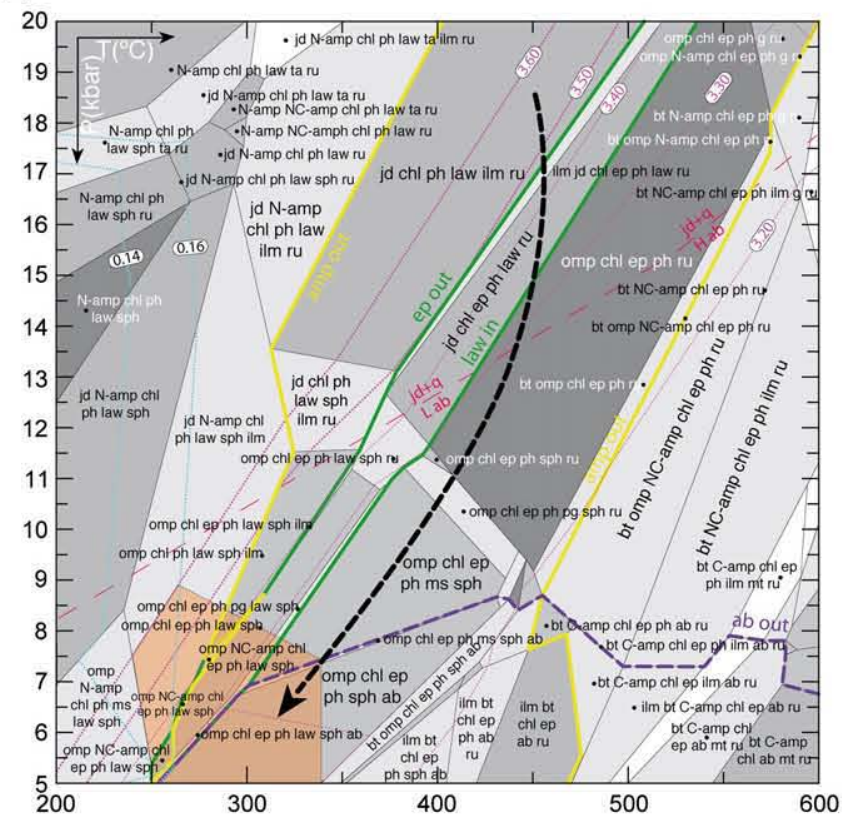

B

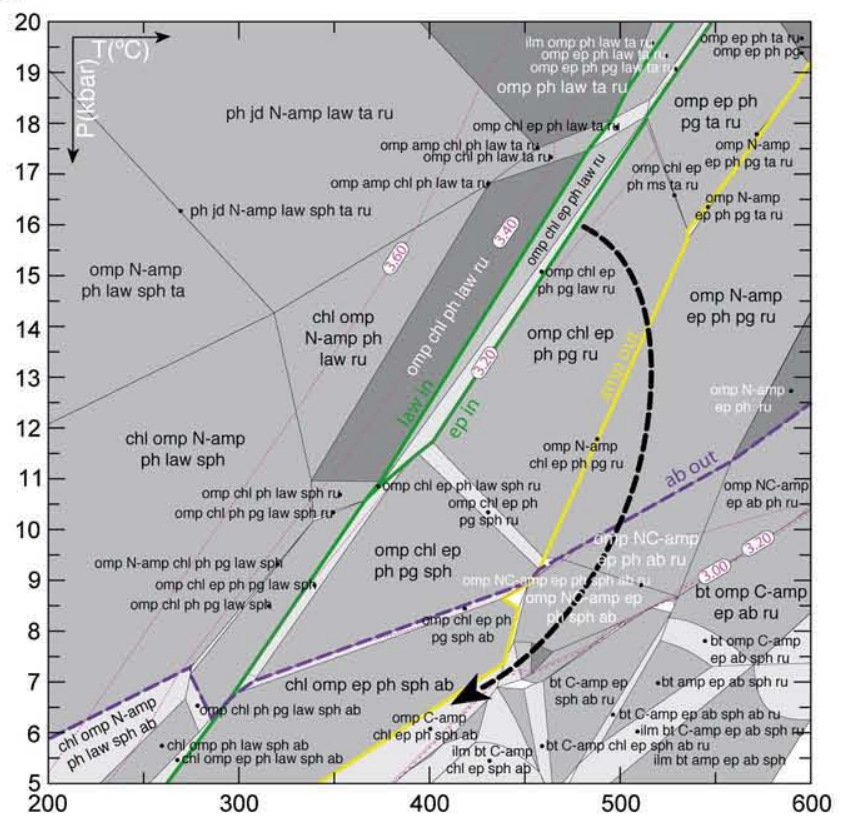

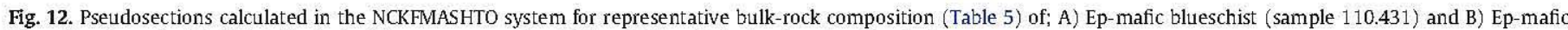
blueschist (sample 110.432). Thin dashed lines correspond to $\mathrm{Fe}^{2+}$ and Si isopleths in phengites (c.p.f.u.). 


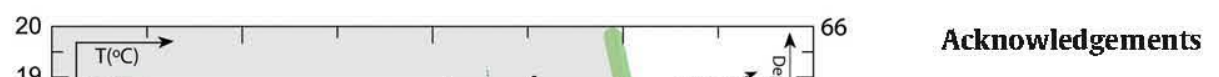

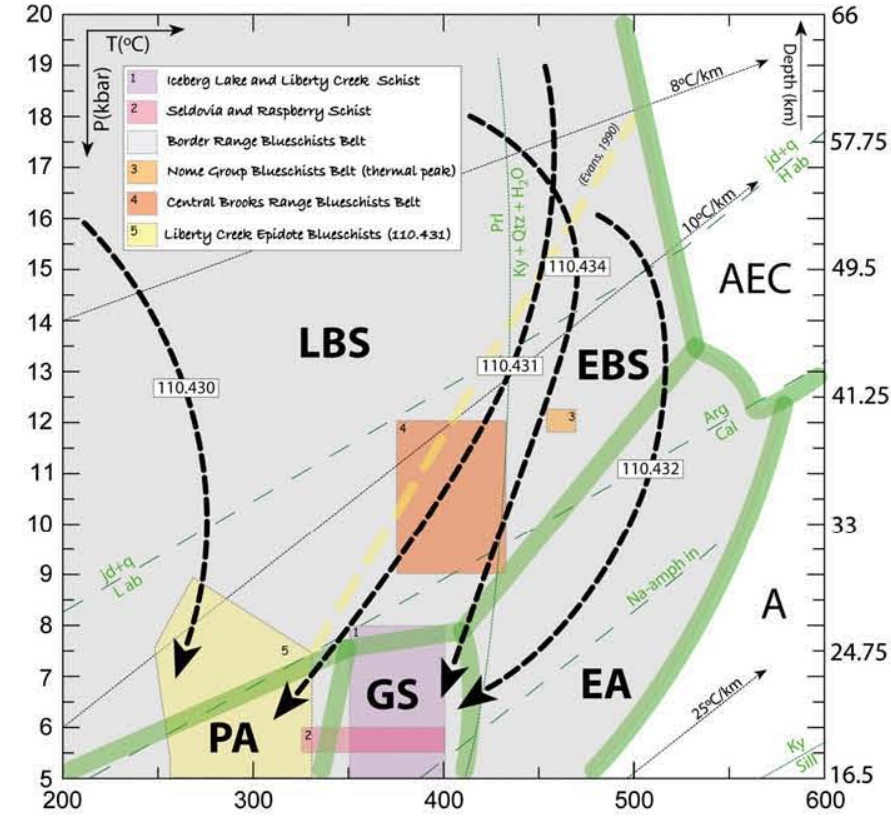

Fig. 13. P-T diagram showing the metamorphic paths of the Liberty Creek Schists. Dashed thin lines refer to different diagnostic reactions: Jd + Qtz $\rightarrow \mathrm{Ab}$ (Holland 1980); $\operatorname{Prl} \rightarrow \mathrm{Ky}+\mathrm{Qtz}+\mathrm{H}_{2} \mathrm{O}$ and aluminosilicate stability fields after Holdaway (1971). Arg = Cal (Johannes and Puhan, 1971), Na-amph in (Maresch (1977), are also shown for reference. Continuous thick lines separate facies fields simplified after Maruyama et al. (1996) and Evans (1990). Thick continuous lines represent the calculated $P-T$ paths. Facies field abbreviations: PA, pumpellyite-actinolite facies; GS, greenschist facies; EA, epidote-amphibolite facies; A, amphibolite facies; LBS, lawsonite blueschist facies; EBS, epidote blueschist facies and AEC, amphibole eclogite facies. For comparison, previous $P-T$ estimations for the Liberty Creek Schist are shown; $P-T$ paths from Iceberg Lake (Sisson and Onstott, 1986); Seldovia and Raspberry Schist (Carden et al., 1977); Border Range Blueschists Belt (Roeske, 1986; Roeske et al., 1989); Nome Group Blueschists Belt (Patrick and Evans, 1989); Central Brooks Range Blueschists Belt (Patrick, 1995) are also included.

initiation of subduction and the metamorphism in the blueschist belts. This estimate is based on the difference in age between the $230 \mathrm{Ma}$ (Norian) $\mathrm{U} / \mathrm{Pb}$ age of the Halibut cove SSZ ophiolite crust (Kusky and Glass, 2007), and 230 Ma tuffs in Port Graham formation, and the $190 \mathrm{Ma}$ age of the Seldovia and Liberty Creek metamorphism. So, if it took a maximum of 40 Ma to subduct the protoliths of the Seldovia and Liberty Creek blueschist to depths of perhaps $50-55 \mathrm{~km}$, we estimate a minimum vertical component of subduction of $1.2-1.5 \mathrm{~cm} /$ year. True rates are likely to be faster.

More interestingly, we speculate on why blueschist facies rocks only appear to be preserved in a few very narrow fault-bounded strips adjacent to the Border Ranges fault. Several ideas are possible and require testing. First, the Border Ranges fault may be responsible for exhuming the blueschist facies rocks from depth, and they are only preserved adjacent to the fault because this is the only place they were brought close to the surface. Second, it is possible that blueschist facies assemblages are preserved because the Border Ranges fault marks the site of the initial subduction, where a cold oceanic slab thermally insulated material brought to about 50-55 km depth before they were returned (buoyantly?) to the surface. The Border Ranges fault is now largely a major strike-slip fault (Little and Naeser, 1989; Pavlis and Roeske, 2007), but the correlation of the blueschists with the trace of the fault support its earlier history as a subduction thrust (Plafker and Berg, 1994; Plafker et al., 1989). It is also interesting in this respect that all three preserved blueschist belts in this setting are long and narrow lens-shaped bodies, perhaps aiding their rapid return to the surface as demonstrated by the fast isothermal decompression documented in this study, and suggested for other HP terrains around the world (e.g., Wang et al., 2010).
Field work in the Seldovia quadrangle was the Alaska Mineral Resource Assessment Program of the USGS. Tim Kusky received funding, in addition, from the National Science Foundation Grants EAR-9304647 and EAR-9706699. Additional funds were provided by the National Natural Science Foundation of China (Grant 40821061) and the Ministry of Education of China (B07039). Laboratory work was financially supported by the CGL2007-65338-C02-01 project provided by the Spanish Ministry of Science and Innovation. We thank our colleagues Dwight Bradley, Alison Hill, and George Plafker of the USGS, and Erkan Toroman, for collaboration in the field and sharing samples and data. We also thank the Co-editor Dr. Ian Buick, Dr. Stephen T. Johnston and Dr. Lucie Tajcmanova for their constructive revisions that significantly improved the quality of this manuscript.

\section{References}

Andersen, D.J., Lindsley, D.H., 1988. Internally consistent solution models for Fe-MgMn-Ti oxides - Fe-Ti oxides. American Mineralogist 73, 714-726.

Armbuster, T., Bonazzi, P., Akasaka, M., Bermanex, V., Chopin, C., Giere, R., HeussAssbichler, Liebscher, A., Menchettic, S., Pan, Y., Pasero, M., 2006. Recommended nomenclature of epidote-group minerals. European Journal of Mineralogy 18, 551-567.

Atherton, M.P., Brotherton, M.S., 1982. Major element composition of the pelites of the Scottish Dalradian. Geological Journal 17, 185-221.

Auzanneau, E., Schmidt, M.W., Vielzeuf, D., Connolly, J.A.D., 2010. Titanium in phengite: a geobarometer for high temperature eclogites. Contributions to Mineralogy and Petrology 159, 1-24.

Bradley, Dwight C., Kusky, Timothy M., Karl, Susan M., Haeussler, Peter J., 1997. Field guide to the Mesozoic accretionary complex along Turnagain Arm and Kachemak Bay, south-central Alaska. In: Karl, S.M., Vaughan, N.R., Ryherd, T.J. (Eds.), 1997 Guide to the Geology of the Kenai Peninsula, Alaska: Alaska Geological Society, Anchorage, Alaska, pp. 2-12.

Bradley, D.C., Kusky, T.M., Haeussler, P., Karl, S.M., Donley, D.T., 1999. Geologic map of the Seldovia Quadrangle, U.S. Geological Survey open file report 99-18, scale $1: 250,000$, with marginal notesAlso available as an internet publication: http:// wrgis.wr.usgs.gov/open-file/of99-18/1999.

Bradley, Dwight C., Kusky, Timothy M., Karl, Susan M., Till, Alison, Haeussler, Peter J., 2000. Field guide to the Mesozoic Accretionary Complex in Kachemak Bay and Seldovia. South-Central Alaska, Alaska Geological Society and British Petroleum, Anchorage, Alaska, May 12-15, 2000.

Bradley, D.C., Kusky, T.M., Haeussler, P., Rowley, D.C., Goldfarb, R., Nelson, S., 2003. Geologic signature of early ridge subduction in the accretionary wedge, forearc basin, and magmatic arc of south-central Alaska. In: Sisson, V.B., Roeske, S., Pavlis, T.L. (Eds.), Geology of a Transpressional Orogen Developed during a Ridge-Trench Interaction along the North Pacific Margin: Geological Society of America Special Paper, 371, pp. 19-50.

Carden, J.R., Decker, J.E., 1977. Tectonic significance of the Knik River schist terrane, south-central Alaska, in short notes on Alaskan geology: Alaska Division of Geological and Geophysical Surveys. Geologic Report 55, 7-9.

Carden, J.R., Forbes, R.B., 1976. Discovery of blueschists in Kodiak Islands, Alaska, in short notes on Alaskan geology: Alaska Division of Geological and Geophysical Surveys. Geologic Rep. 51, 19-22.

Carden, J.R., Connelly, W., Forbes, R.B., Turner, D.L., 1977. Blueschists of the Kodiak Islands, Alaska: an extension of the Seldovia schist terrane. Geology 5, 529-533.

Coggon, R. Holland, T.J.B., 2002. Mixing properties of phengitic micas and revised garnet-phengite thermobarometers. Journal of Metamorphic Geology 20, 683-696.

Coney, P.J., Jones, D.L., Monger, J.W.H., 1980. Cordilleran suspect terranes. Nature 288, 329-333.

Connolly, J.A.D., 1990. Multivariable phase diagrams; an algorithm based on generalized thermodynamics. American Journal of Science 290, 666-718.

Connolly, J.A.D., 2005. Computation of phase equilibria by linear programming: a tool for geodynamic modeling and its application to subduction zone decarbonation. Earth and Planetary Science Letters 236, 524-541.

Davis, P.B., Whitney, D.L., 2006. Petrogenesis of lawsonite and epidote eclogite and blueschist, Sivrihisar Massif, Turkey. Journal of Metamorphic Geology 24, 823-849.

Diener, J.F.A., Powell, R., White, R, Holand, T.J.B., 2007. A new thermodynamic model for clino- and orthoamphiboles in the system $\mathrm{Na}_{2} \mathrm{O}-\mathrm{CaO}-\mathrm{FeO}-\mathrm{MgO}-\mathrm{Al}_{2} \mathrm{O}_{3}-\mathrm{SiO}_{2}-\mathrm{H}_{2} \mathrm{O}-\mathrm{O}$. Journal of Metamorphic Geology 25, 631-656.

Ernst, W.G., 2010. Subduction-zone metamorphism, calc-alkaline magmatism, and convergent-margin crustal evolution. Gondwana Research 18, 8-16.

Evans, B.W., 1990. Phase relations of epidote-blueschists. Lithos 25, 3-23.

Green, E.C.R., Holland, T.J.B., Powell, R., 2007. An order-disorder model for omphacitic pyroxenes in the system jadeite-diopside-hedenbergite-acmite, with applications to eclogite rocks. American Mineralogist 92, 1181-1189.

Hallimond, A.F., 1943. On the graphical representation of the calciferous amphiboles. American Mineralogist 28 (2), 65-89.

Heinrich, W., Althaus, E., 1988. Experimental determination of the reaction 4 lawsonite + 1 albite $=1$ paragonite +2 zoisite +2 quartz $+6 \mathrm{H}_{2} \mathrm{O}$ and 4 lawsonite +1 
jadeite $=1$ paragonite +2 zoisite +1 quartz $+6 \mathrm{H}_{2} \mathrm{O}$. Neues Jahrbuch fur $\mathrm{r}$ Mineralogie Monatshefte 11, 516-528.

Hey, M.H., 1954. A new review of the chlorites. Mineralogical Magazine 30, 277-292.

Holdaway, M.J., 1971. Stability of andalusite and the aluminum silicate phase diagram. American Journal of Science 211,97-131.

Holland, T., 1980. The reaction albite $=$ jadeite + quartz determined experimentally in the range $600-1200^{\circ} \mathrm{C}$. American Mineralogist $65,125-134$.

Holland, T.J.B., Powell, R., 1998. An internally consistent thermodynamic data set for phases of petrological interest. Journal of Metamorphic Geology 16. 309-343.

Isozaki, Y., Aoki, K., Nakama, T., Yanai, S., 2010. New insight into a subduction-related orogen: a reappraisal of the geotectonic framework and evolution of the Japanese Islands. Gondwana Research 18, 82-105. doi:10.1016/j.gr.2010.02.015.

Johannes, W., Puhan, D., 1971. The calcite-aragonite transition, reinvestigated. Contributions to Mineralogy and Petrology 31, 225-228.

Kadarusman, A., Maruyama, S., Kaneko, Y., Ota, T., Ishikawa, A, Sopaheluwakan, J., Omori, S., 2010. World's youngest blueschist belt from Leti Island in the nonvolcanic Banda outer arc of Eastern Indonesia. Gondwana Research 18, 189-204. doi:10.1016/j.gr.2010.02.009.

Kretz, R., 1983. Symbols for rock-forming minerals. American Mineralogist 68, 277-279.

Kusky, T.M., Bradley, D.C., 1999. Kinematics of mélange fabrics: examples and applications from the McHugh Complex, Kenai Peninsula, Alaska. Journal of Structural Geology 21 (12), 1773-1796.

Kusky, T.M., Glass, A., 2007. Structure, Cr-chemistry, and age of the border ranges ultramafic/mafic complex: a suprasubduction zone ophiolite complex. Geological Society of America, Special Paper 431 on the Tectonic Growth of a Collisional Continental Margin: Crustal Evolution of Southern Alaska, pp. 207-225. doi:10.1130/ 2007.2431(09).

Kusky, T.M., Bradley, D.C., Haeussler, P.J., 1997a. Progressive deformation of the Chugach accretionary complex, Alaska, during a Paleogene ridge-trench encounter. Journal of Structural Geology 19, 139-157.

Kusky, T.M., Bradley, D.C., Haeussler, P., Karl, S., 1997b. Controls on accretion of flysch and mélange belts at convergent margins: evidence from the Chugach Bay thrust and Iceworm mélange, Chugach Terrane, Alaska. Tectonics 16 (6), $855-878$.

Kusky, T.M., Bradley, D.C., Donley, D.T., Rowley, D., Haeussler, P., 2003. Controls on intrusion of near-trench magmas of the Sanak-Baranof belt, Alaska, during Paleogene ridge subduction, and consequences for forearc evolution. In: Sisson, V.B., Roeske, S., Pavlis, T.L. (Eds.), Geology of a Transpressional Orogen Developed During a Ridge-Trench Interaction Along the North Pacific Margin: Geological Society of America Special Paper, 371, pp. 269-292.

Leake, B.E., Woolley, A.R., Arpes, C.E.S., et al., 1997. Nomenclature of amphiboles: report of the Subcommittee on amphiboles of the International Mineralogical Association, Commission on New Minerals and Mineral Names. American Mineralogist 82, 1019-1037.

Little, T.A., Naeser, C.W., 1989. Tertiary tectonics of the Border Ranges fault system, Chugach Mountains, Alaska: deformation and uplift in a forearc setting. Journal of Geophysical Research 94, 4333-4359.

López-Carmona, A., Abati, J., Reche, J., 2010. Petrologic modeling of chloritoidglaucophane schists from the NW Iberian Massif. Gondwana Research 17, 377-391.

Maresch, W., 1977. Experimental studies on glaucophane: an analysis of present knowledge. Tectonophysics 43, 109-125.

Maruyama, S., Liou, J.G., Terabayashi, M., 1996. Blueschists and eclogite of the world and their exhumation. International Geological Review 38, 485-594.

Maruyama, S., Hasegawa, A., Santosh, M., Kogiso, T., Nakamura, H., Kawai, K., Zhao, D., 2009. The dynamics of big mantle wedge, magma factory, and metamorphicmetasomatic factory in subduction zones. Gondwana Research 16,414-430.

Massone, H.J., Schreyer, W., 1987. Phengite geobarometry based on the limiting assemblage with K-feldspar, phlogopite and quartz. Contributions to Mineralogy and Petrology 96, 212-214.

Miyashiro, A., 1973. Metamorphism and Metamorphic Belts. G. Allen and Unwin Publications, London.

Mottana, A., Schreyer, W., 1977. Carpholite crystal chemistry and preliminary experimental stability. Neues Jahrbuch für Mineralogie 129, 113-138.

Newton, R.C., Charlu, T.V., Kleppa, O.J., 1980. Thermochemistry of the high structural state plagioclases. Geochemica and Cosmochimica Acta 44, 933-941.

Nilsen, T.H., Zuffa, G.G., 1982. The Chugach terrane, a Cretaceous trench-fill deposit, southern Alaska. Geological Society of London. Special Publication 10, 213-227. basin, eastern Alaska Range, and southern Yukon-Tanana Basin, southern and eastcentral Aslaska. In: Nokleberg, W.J., Fisher, M.A. (Eds.), Alaskan Geological and Geophysical Transect: International Geological Congress, 27th, Guidebook T104, pp. 34-64.

Nokleberg, W.J., Plafker, G., Wilson, F.H., 1994. Geology of south-central Alaska. In: Plafker, G., Berg, H.C. (Eds.), The Geology of Alaska, Decade of North American Geology vol. G-1: Geological Society of America, pp. 311-366.

Omori, S., Kita, S., Maruyama, S., Santosh, M., 2009. Pressure-temperature conditions of ongoing regional metamorphism beneath the Japanese Islands. Gondwana Research 16, 458-469.

Ota, T., Kaneko, Y., 2010. Blueschists, eclogites, and subduction zone tectonics: Insights from a review of Late Miocene blueschists and eclogites, and related highpressure metamorphic rocks. Gondwana Research 18, 167-188. doi:10.1016/j. gr.2010.02.013.

Patrick, B.E., 1995. High pressure-low temperatura metamorphism of granitic orthogneisses in the Brooks Range, northern Alaska. Journal of Metamorphic Geology 13, 111-124.

Patrick, B.E., Evans, B.W., 1989. Metamorphic evolution of the Seward Peninsula blueschist terrane. Journal of Petrology 30, 531-555.

Pavlis, T.L., Roeske, S.M., 2007. The Border Ranges fault system, southern Alaska. In: Ridgeway, K.D., Trop, J.M., Glen, J.M.G., O'Oneill, J.M. (Eds.), Tectonic Growth of a Collisional Continental Margin: Crustal Evolution of Southern Alaska: Geological Society of America Special Paper, 431, pp. 95-127.

Plafker, G., Berg, H.C., 1994. Overview of the Geology and Tectonic Evolution of Alaska. In: Plafker, G., Berg, H. (Eds.), The Geology of North America: The Geology of Alaska, Geological Society of America, vol. G-1, pp. 989-1021. Chapter 33.

Plafker, G., Nokleberg, W.J., Lull, J.S., 1989. Bedrock geology and tectonic evolution of the Wrangellia, Peninsular, and Chugach terranes along the Trans-Alaska Crustal Transect in the Chugach Mountains and southern Copper River basin. Journal of Geophysical Research 94, 4255-4295.

Poli, S., Schmidt, M.W., 2002. Petrology of subducted slabs. Annual Review of Earth and Planetary Sciences 30, 207-235.

Roeske, S.M., 1986. Field relations and metamorphism of the Raspberry Schist, Kodiak Islands, Alaska. Blueschists and eclogites. In: Evans, B.W., Brown, E.H. (Eds.) Geological Society of America Memoir, 164, pp. 169-184.

Roeske, S.M., Mattison, J.M., Armstrong, R.L., 1989. Isotopic ages of glaucophane schist on the Kodiak Islands, southern Alaska, and their implications for the Mesozoic tectonic history of the Border Ranges Fault system. Geological Society of America Bulletin 101, 1021-1037.

Sisson, V.B., Onstott, T.C., 1986. Dating blueschist metamorphism; a combined 40Ar $39 \mathrm{Ar}$ and electron microprobe approach. Geochimica et Cosmochimica Acta 50 , 2111-2117.

Tajcmanová, L., Connolly, J.A.D., Cesare, B., 2009. A thermodynamic model for titanium and ferric iron solution in biotite. Journal of Metamorphic Geology 27, $153-164$.

Tsujimori, T., Sisson, V.B., Liou, J.G., Harlow, G.E., Sorensen, S.S., 2006. Very-lowtemperature record of the subduction process: a review of worldwide lawsonite eclogites. Lithos 92, 609-624.

Viereck, L.G., Flower, M.F.J., Hertogen, J., Schmincke, H.-U., Jenner, G.A., 1989. The genesis and significance of N-MORB sub-types. Contributions to Mineralogy and Petrology 102, 112-126.

Wang, Lu., Kusky, T., Li, S.Z., 2010. Structural geometry and evolution of an exhumed ultra-high pressure eclogite massif, Yangkou Bay, Sulu Belt, China. Journal of Structural Geology 32, 423-444.

White, R., Powell, R., Holland, T.J.B., Worley, B.A., 2000. The effect of $\mathrm{TiO}_{2}$ and $\mathrm{Fe}_{2} \mathrm{O}_{3}$ on metapelitic assemblages at greenschist and amphibolite facies conditions: mineral equilibria calculations in the system $\mathrm{K}_{2} \mathrm{O}-\mathrm{FeO}-\mathrm{MgO}-\mathrm{Al}_{2} \mathrm{O}_{3}-\mathrm{SiO}_{2}-\mathrm{H}_{2} \mathrm{O}-\mathrm{TiO}_{2}-\mathrm{Fe}_{2} \mathrm{O}_{3}$. Journal of Metamorphic Geology 18, 497-511.

Whitney, D.L., Evans, B.W., 2010. Abbreviations for names of rock-forming minerals. American Mineralogist 95, 185-187.

Zhang, L., Wang, Q, Song, S., 2009a. Lawsonite blueschist in Northern Qilian, NW China: P-I pseudosections and petrologic implications. Joumal of Asian Earth Sciences 35, 354-366.

Zhang, Z., Zhu, W., Shu, L., Wan, J., Yang, W., Su, J., Zheng, B., 2009b. Apatite fission track thermochronology of the Precambrian Aksu blueschist, NW China: implications for thermo-tectonic evolution of the north Tarim basement. Gondwana Research 16 , $182-188$. 